\title{
Az immobilitást növelő és csökkentő települési jellemzők
}

\author{
KERÜLŐ JUDIT ${ }^{1}$
}

\begin{abstract}
ABSZTRAKT
A tanulmány arra a kérdésre keresi a választ, milyen okokkal magyarázható a kistelepüléseken, fóként hátrányos helyzetü községekben való ott maradás akkor, amikor több előny származik a városban éléstől. 104 interjú alapján, 13 település esetében elemezzük az okokat, a vonzó és taszító tényezőket. Az interjúk meggyőzően igazolják, hogy az elköltözés vagy helyben maradás kérdéséről való döntés komplex, soktényezős folyamat. Ebben kétségtelenül fontos, de nem kizárólagos szerepe van a foglalkoztatási lehetőségeknek. Összefüggésben áll az egyén demográfiai jellemzőivel, nemével, életkorával, családi állapotával, munkaerôpiaci jellemzőivel, iskolai végzettségével, anyagi, vagyoni helyzetével, egyéni sajátosságaival, egészségi állapotával, a változásokkal kapcsolatos attitüdjével, etnikai hátterével és az adott településsel való elégedettségével is.
\end{abstract}

KULCSSZAVAK: települési jellemzők, immobilitást növelő, csökkentő tényezôk

\section{ABSTRACT}

\section{Municipal Characteristics Increasing and Decreasing Immobility}

The study looks for answers to the question: what are the reasons behind staying in small municipalities, especially in highly disadvantaged villages, when moving into cities offers obvious advantages. We have analysed the motives, as well as attractive and repulsive factors based on 104 interviews, in case of 13 municipalities. The interviews convincingly certify that the decision about moving or staying in one place is a complex, multifactorial process. In this, employment opportunities have an undeniably important, however, not completely exclusive role. It is correlated with the demographic characteristics, gender, age, family status, labour market parameters, education level, financial characteristics, individual peculiarities, health status of the individual, as well as with its attitude towards changes, ethnic background, and its contentment concerning the given settlement.

KEYWORDS: Municipal Charecteristics, Increasing and Decreasing Immobility

\footnotetext{
${ }^{1}$ Főiskolai tanár, Nyíregyházi Egyetem Szociálpedagógia Intézeti Tanszék, kerulo.judit@nye.hu
} 


\section{TEMATIKUS TANULMÁNYOK - Községekben élő immobil fiatalok}

\section{Bevezetés}

Az immobil kutatás célja, hogy választ kapjunk arra a kérdésre, milyen okokkal magyarázható, indokolható a faluban maradás jelensége akkor, amikor minden tekintetben több előny származik a városi létből. A tanulmány az MTA Kiválósági Együttmüködési Programja, Mobilitás Kutatási Centrum projektje keretében a Debreceni Egyetemen, a 19-25 év közötti falusi fiatalok körében lezajlott kutatás adataira támaszkodik. Olyan fiatalokkal készültek interjúk, akik már befejezték tanulmányaikat, de falujukban maradtak, és akiknek a szüleik is ugyanazon a településen élnek. Az interjúalanyokat nem valószínűségi mintavétellel választottuk ki.

A kutatás 13 településen történt, megyei bontásban három Borsod-Abaúj-Zemplén, kettő Hajdú-Bihar, egy Heves, hat Szabolcs-Szatmár-Bereg és egy Jász-Nagykun-Szolnok megyében található.

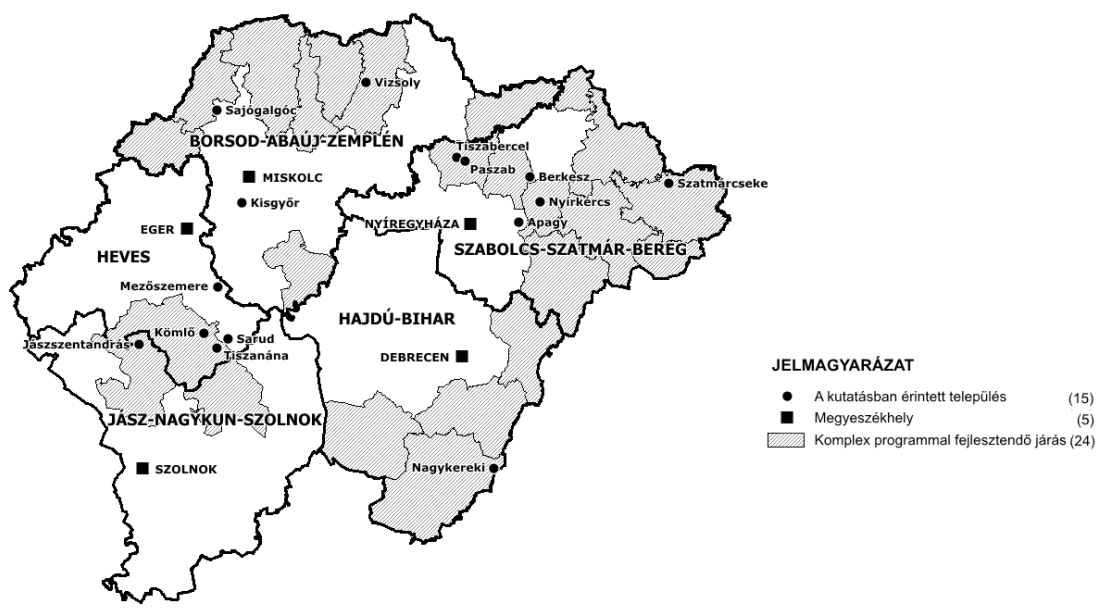

1. ábra: A kutatásba bevont települések

Forrás: Balcsók István saját szerkesztése, 2019

Többségében hátrányos helyzetű, közigazgatási besorolásuk alapján községekben készült el a vizsgálat alapját képező 104 interjú. A településmérettel kapcsolatban egyetlen követelmény az volt, hogy az ott élők száma ne haladja meg a 2500 főt. A települések, ahogy azt az 1. számú táblázat is mutatja, lakónépességük alapján eltérő nagyságúak. Három község lakóinak száma meghaladja a 2 ezer főt, hat település lakónépessége 1 és 2 ezer közötti és háromban ezer főnél is kevesebben laknak. Az 1. számú táblázat adatai szerint a vizsgált 13 településből 9 jelentős munkanélküliséggel sújtott és mindössze 4 olyan község volt, ahol a munkanélküliség az országos adatokkal megegyező volt. 
www. metszetek.unideb.hu

\section{TEMATIKUS TANULMÁNYOK - KöZségekben élő immobil fiatalok}

1. táblázat: A vizsgált települések lakónépesség szerinti megoszlása, 2018

\begin{tabular}{|l|l|c|c|}
\hline \multicolumn{1}{|c|}{ Település neve } & \multicolumn{1}{c|}{ Megye } & $\begin{array}{c}\text { Lakónépessége } \\
\text { 2018-ban }\end{array}$ & $\begin{array}{c}\text { Jelentős } \\
\text { munkanélküliséggel sújtott }\end{array}$ \\
\hline Tiszanána & Heves & 2495 & Igen \\
\hline Jászszentandrás & Jász-Nagykun-Szolnok & 2393 & Nem \\
\hline Apagy & Szabolcs-Szatmár-Bereg & 2340 & Nem \\
\hline Hajdúbagos & Hajdú-Bihar & 1994 & Igen \\
\hline Tiszabercel & Szabolcs-Szatmár-Bereg & 1797 & Igen \\
\hline Kisgyőr & Borsod-Abaúj-Zemplén & 1655 & Igen \\
\hline Szatmárcseke & Szabolcs-Szatmár-Bereg & 1594 & Igen \\
\hline Nagykereki & Hajdú-Bihar & 1350 & Igen \\
\hline Paszab & Szabolcs-Szatmár-Bereg & 1177 & Igen \\
\hline Berkesz & Szabolcs-Szatmár-Bereg & 866 & Nem \\
\hline Vizsoly & Borsod-Abaúj-Zemplén & 830 & Igen \\
\hline Nyírkércs & Szabolcs-Szatmár-Bereg & 799 & Nem \\
\hline Sajógalgóc & Borsod-Abaúj-Zemplén & 313 & Igen \\
\hline
\end{tabular}

Forrás: Saját szerkesztés Magyarország helységnévtára 2018. adatai alapján²

A továbbiakban először a jelentős munkanélküliséggel sújtott településeket mutatom be lakónépességük alapján csökkenő sorrendben, ezt követően a munkanélküliségi problémával kevésbé érintettek következnek, szintén a lakónépességi adatok sorrendjében. A 105/2015.(IV.23.) Kormányrendelet jelentős munkanélküliséggel sújtott településnek tekinti azokat a településeket, amelyekben a munkanélküliségi ráta meghaladja az országos átlag 1,75 szeresét (www.netjogtar.hu).

Az elemzéseket a települések bemutatásával kezdem, földrajzi fekvés, demográfiai adatok és munkahelyek alapján. Ehhez Magyarország helységnévtára 2018. évi adatait használtam fel és a település honlapjáról tájékozódtam. Ezt követően az interjúk elemzésére kerül sor. A kapott válaszok alapján arra a kérdésre keresem a választ, hogy a megkérdezettek milyen szempontok alapján tartják a településeket élhetőnek, azaz miért gondolják úgy, hogy jó vagy nem jó itt lakni. Továbbá, hogy látják a más környékbeli településsel összehasonlítva az itteni életet. Azt is elemzem, milyen okokkal magyarázzák azt, hogy itt, ezen a településen maradnak. Arra is kíváncsi voltam továbbá, hogy a városok által nyújtott kedvezőbb lehetőségek ellenére az adott település milyen előnyöket tud biztosítani az ott lakók számára, azaz milyen településsel kapcsolatos tényezők erősítik vagy gyengítik a megkérdezettek immobilitását.

\footnotetext{
${ }^{2}$ http://www.ksh.hu/apps/hntr.main?p_lang=HU
} 


\section{TEMATIKUS TANULMÁNYOK - Községekben élő immobil fiatalok}

\section{Jelentős munkanélküliséggel sújtott települések lakónépesség szerinti csökkenő sorrendben}

\section{I.1. TISZANÁNA}

Tiszanána Heves megyében, a Hevesi járásban található község. A hozzá legközelebbi város Kisköre, 10 kilométerre van a falutól. Keleten Saruddal, északon Kömlővel, nyugaton Kiskörével határos. Déli határát a Tisza folyó alkotja, mely a községtől 5 km-re fekszik. Szabályos alaprajzú, út menti falu, déli és északkeleti részén egy-egy templommal. Kisköre, Poroszló és Füzesabony irányába vezető útjai révén az országúti közlekedés kisebb jelentőségú gócpontja.

Az itt élők jellemzően mezőgazdasággal foglalkoznak, de a Tisza közelsége is fontos a település életében. Csónakkikötője több száz csónak befogadására alkalmas, strandját a Tisza legromantikusabb strandjának tartják. A terület viszonylagosan jó fekvése ellenére potenciáljához képest alulfejlett. Sajnos 2017-ig nem nyert semmilyen fejlesztési Forrás:t turizmusának fejlesztésére, míg a környező települések (Poroszló, Tiszafüred, Abádszalók) jelentős pénzösszeggel tudták fejleszteni kínálatukat és szolgáltatásaik minőségét. 2018-ban nyert uniós pályázata révén a fejlesztések segítségével Tiszanána a tó egyik legfontosabb kikötőjévé válhat, jelentős számú új hajót tud majd befogadni, illetve tárolni. Ez várhatóan áttörést fog hozni a látogatottságban, és katalizálni fogja a magánvállalkozók turisztikai fejlesztéseit is. A beruházások révén mind a lakosság, mind az ide látogató turisták magasabb szintű szolgáltatásokat tudnak majd igénybe venni. ${ }^{3}$

2. táblázat: Tiszanána lakónépességének alakulása 1990-2018 között*

\begin{tabular}{|c|c|}
\hline Évszám & Lakónépesség főben \\
\hline 2018 & 2493 \\
\hline 2017 & 2475 \\
\hline 2016 & 2480 \\
\hline 2015 & 2474 \\
\hline 2014 & 2482 \\
\hline 2013 & 2508 \\
\hline 2012 & 2538 \\
\hline 2011 & 2541 \\
\hline 2001 & 2644 \\
\hline 1990 & 2662 \\
\hline
\end{tabular}

* Az adatok január 1-ei állapotot mutatnak, a népszámlálás évében $(2011,2001,1990)$ az eszmei időpontra vonatkoznak.

Forrás: Saját szerkesztés Magyarország helységnévtára 2018. adatai alapján ${ }^{4}$

\footnotetext{
${ }^{3}$ https://tiszanana.hu/2015/04/19/polgarmesteri-koeszoent/

${ }^{4}$ http://www.ksh.hu/apps/hntr.telepules?p_lang=HU\&p_id=07083
} 


\section{TEMATIKUS TANULMÁNYOK - Községekben élő immobil fiatalok}

Az adatok azt jelzik, hogy a vizsgált időszakban jelentősen csökkent a község lakónépessége. A csökkenés folyamatos tendenciát mutat. Az eltéréseket főként az élveszületések és a halálozások számának évenkénti ingadozása magyarázza. Ugyanakkor a lakónépesség tendenciaszerü fogyását a vándorlás indokolja. Az elvándorlók száma a vizsgálat időszakban minden évben meghaladta az odavándorlókét.

A település foglalkoztatás szempontjából kedvezőtlen helyzetét mutatja, hogy bár a regisztrált munkanélküliek aránya 2008 és 2015 között csökkent, de még így is közel háromszorosa az országosnak és jelentősen magasabb, mint a Heves megyei és a Hevesi járásban mért érték. A munkanélküliek több mint fele tartós munkanélküli. A pályakezdő munkanélküliek körében tapasztalható csökkenés valószínűsíthetően a számukra leginkább elérhető közmunkával van összefüggésben. A település hátrányos helyzetét igazolja, hogy az itt élők nettó jövedelme 2014-ben közel fele volt az országos és a Heves megyei értéknek és jelentősen alulmúlta a régióbeli és járási jövedelmeket is (Loncsák 2018). A településen magas a roma lakosság aránya, a 2011es népszámlálási adatok alapján az itt élők 20\%-a romaként jelölte meg nemzetiségét. Ôk főként szegregátumban élnek. A település 2018-ban 198 millió forintot nyert pályázaton a romák helyzetének javítására és társadalmi integrációjuk elősegítésére (Orbán 2018).

\section{I.1.1. A faluban maradás indokai}

A megkérdezettek jellemzően alacsony iskolai végzettségűek, általános iskolai végzettséggel rendelkeznek, de interjú készült egy szakmunkás, egy érettségizett és egy diploma előtt álló tiszanánai lakossal is. Valamennyi megkérdezett esetében a helyben maradás legfontosabb indoka „az itt születtem, itt élnek a szüleim, rokonaim.” Ezek a kötelékek fontosak számukra, hisz ez jelenti az állandóságot, ismertséget és biztonságot.

„Hát mert ez a szülöfaluja, itt születtünk, itt voltak a sok ismerősök, még mai napig is, kisjányom, és azé,' azé' szerettünk itt lakni. És itt maradni. Ennyi." (64 éves nö, 3 osztályt végzett)

„Hát ö... hát ide vagyunk szokva.” (21 éves nő, 8 ált. iskolai végzettség)

„Hát mer' itt születtünk. Mink szeretünk itt élni. Itt is akarunk meghalni.” (60 éves nö, 8 ált. iskolai végzettség)

Ezt követően az interjúalanyok a biztonság fontos tényezőjeként említik az önkormányzattal és főként a polgármesterrel való elégedettségüket. 


\section{TEMATIKUS TANULMÁNYOK - Községekben élő immobil fiatalok}

„És nagyon sok újítás is történt. Például az általános iskolát, ö... a tornatermet, a templomot, a buszmegállót, a tüzoltóságot felújították, ami számomra és a leendő munkahelyem szempontjából fontos. És ö... fontosak számunkra az is, hogy látjuk, hogy fejlődik a falu." (25 éves nö, érettségizett, egyetemi hallgató)

Feltételezhető, hogy a roma válaszadók számára jelent nagyobb biztonságot, hogy a település polgármestere is roma lett.

„[R]oma lett a polgármester, így jobban ö... oda lettek figyelve a romákra." (23 éves férfi, 8 ált. iskolai végzettség)

„Hát körülbelül 2 éve polgármesterváltás történt, ö... azok elött elég szegényes volt a helyzet, de most már kezd a falu is teljesen ö... mobilizálódni, most már egész jó." (47 éves nő, 8 ált. iskolai végzettség)

„Itt nagyon jó emberek vannak, kedvesek és jók. A polgármester is sokat segít, kedvesek a hivatalba." (64 éves nö, 3 osztályt végzett)

Gazdasági racionális szempontok is megjelennek mint immobilitási tényezők, „alacsonyabb megélhetési költségek” és az „olcsóbb ingatlanok” indoklással.

„Szerettünk volna, hogyha Egerhez közel lenne házunk, de mivel ezt itt építettük, nem sikerült eladni és ott venni telket, úgyhogy röviden ennyi, itt maradtunk." (40 éves nö, szakmunkás)

„Én még nem tehetem meg anyagilag, hogy vegyek egy másik házat. De gyuujtök rá." (22 éves férfi, 8 ált. iskolai végzettség)

„Hát már megszoktuk, ide születtünk és ö... sajnos anyagi okokból nem is volt rá lehetőség, hogy másik faluba költözzünk." (25 éves nö, érettségizett, egyetemista)

Szintén racionális indokként fogadhatjuk el a település helyzetével összefüggő érveket, a Tisza közelsége, az ehhez kapcsolódó vendéglátás stb. indokokat.

„Hát azért, mert a párom szeret itt lakni, meg tud méhecskézni is itt, úgyhogy röviden ennyi." (40 éves nö, 8 ált. iskolai végzettség)

„És itt szeretnék maradni a párommal is. Ugye meg a tanulmányaim. Vagyis be szeretném még fejezni a tanulmányaimat. Itt szeretnék dolgozni, éttermet nyitni a Tisza melletti strandon." (22 éves nő, érettségizett) 


\section{TEMATIKUS TANULMÁNYOK - KöZségekben élő immobil fiatalok}

Egyetlen olyan interjúalany volt, aki közvetlenül diplomája megszerzése előtt állt. Esetében megjelenik az a kötelem, amely arról szól, segítse azokat az embereket, akiknek köszönheti eddigi tanulmányait, sikereit. Természetesnek tartja, hogy szülőfalujába jöjjön vissza diplomásként is.

„Itt pedig nagyon kevés tényleg, a végzettséggel rendelkező személy, tehát ö... úgy gondolom, hogy elhelyezkedni el fogok tudni. És van is bennem egyfajta olyan motiváció is, hogy segítsek azoknak, akik kilátástalanabbnak látják a helyzetüket is. Igy is példát mutathassak azáltal, hogy ott vagyok, helyben vagyok. Fontos az itteni jelenlétem." (25 éves nő, érettségizett, egyetemista)

\section{I.1.2. Taszító tényezók, ami miatt el akarnak költözni}

Az elköltözést tervezők legfontosabb indoka, hogy helyben nem tudnak megfelelő munkát találni. A településen főként közmunkára van lehetőség. Akik szeretnének rövid időn belül elköltözni, jelenleg sem helyben dolgoznak, hanem az 50 kilométerre lévő Egerben, illetve a 150 kilométerre lévő fővárosban találtak munkát. Mivel a helybeni munkára nem látnak komoly esélyt, emiatt szeretnének gazdasági lehetőségeik függvényében elmenni a településről.

„Igen, el szeretnénk költözni egy városba, de Heves megyén belül. Kb. 5 éven belül tervezem. (23 éves férfi, 8 ált. iskolai végzettség)

„Valamikor el szeretnék költözni Egerhez közel, mert a munka úgy közelebb lenne." (22 éves férfi, 8 ált. iskolai végzettség)

\section{I.2. HAJDÚBAGOS}

Hajdúbagos Hajdú-Bihar megyében, a Derecskei járásban Debrecentől közúton 18 kilométerre fekszik. Vasúti összeköttetése 2009-ben szűnt meg. 1973 és 1990 között Sáránd település társközsége volt, 1990-től önálló község. 


\section{TEMATIKUS TANULMÁNYOK - Községekben élő immobil fiatalok}

3. táblázat: Hajdúbagos lakónépességének alakulása 1990-2018 között*

\begin{tabular}{|c|c|c|}
\hline Évszám & Lakónépesség fóben & Lakóházak száma db \\
\hline 2018 & 1994 & 856 \\
\hline 2017 & 1976 & 856 \\
\hline 2016 & 1949 & 856 \\
\hline 2015 & 1989 & 856 \\
\hline 2014 & 1966 & 856 \\
\hline 2013 & 1996 & 856 \\
\hline 2012 & 1979 & 856 \\
\hline 2011 & 1974 & 856 \\
\hline 2010 & 2011 & 853 \\
\hline 2001 & 1963 & 821 \\
\hline 1990 & 1919 & 776 \\
\hline
\end{tabular}

* Az adatok január 1-re vonatkoznak, kivéve a népszámlálás évét, amikor a népszámlálás eszmei időpontjára érvényesek.

Forrás: Saját szerkesztés Magyarország helységnévtára 2018. adatai alapján ${ }^{5}$

A 3. számú táblázat adatai azt igazolják, hogy a vizsgált 28 év alatt jelentős népességváltozás a településen nem történt. Az évenkénti változások főként a születések és a halálozások ingadozásával magyarázhatóak. A település életét meghatározza Debrecen közelsége, hiszen autóval, közúton 20 perc alatt elérhető. Emiatt ingázó falunak tekinthető, hiszen az itt élők nagy része a megyeszékhelyre jár iskolába, dolgozni, ügyet intézni, szórakozni, ami egyben azt is jelenti, hogy helyben alig van munkára lehetőség. Ami van, az főként közmunka.

„Sok a közmunkás, közfoglalkoztatott. Nem is a közfoglalkoztatott, hanem a közmunkás nagyon sok itt Hajdúbagoson, mivel nincs itt más munkalehetöség. Az önkormányzat biztosít munkát az embereknek, mint közmunkásoknak." (41 éves nő, érettségizett)

\section{I.2.1. A faluban maradás indokai}

Mindösszesen két interjú készült, ezért az itt leírtak egy család álláspontját tükrözik. A megkérdezettek szerint a település legfőbb értéke a megyeszékhelyhez való közelsége és jó buszközlekedése. A lakások számának növekedése is jelzi a költözési szándékot, hiszen a lakónépesség száma alig változott a vizsgált időszakban, de a

${ }^{5}$ http://www.ksh.hu/apps/hntr.telepules?p_lang=HU\&p_id=26170 


\section{TEMATIKUS TANULMÁNYOK - Községekben élő immobil fiatalok}

lakások számában jelentős növekmény tapasztalható, 28 év alatt 80-nal nőtt a lakóházak száma. Az építkezések 1990 és 2011 között történtek, azóta változást nem mutatnak az adatok.

„Relatíve elég közel is van Debrecenhez és Debrecenben elég sok munkalehetöség van. A buszközlekedés az tényleg nagyon rugalmas, ahhoz képest, hogy Debrecenhez 20 km az elég sok és úgy óránként jönnek buszok." (20 éves férfi, technikus)

A nagyváros könnyű és gyors elérhetőségéhez hozzákapcsolhatóak a falusi lét előnyei, a csend, a városi élethez képest nyugodt légkör.

„De viszont csendes környék. Nem olyan, mint Debrecenben a belváros. Csendes környék." (20 éves férfi, technikus)

„Én azért szeretek itt élni, mert csend van, nyugalom. Távol a város zajától, mert én nagyon sok évig Debrecenbe jártam dolgozni és engem megnyugtat, kifejezetten megnyugtat ez a falusi környezet. Meg szeretem, hogy az emberek ismerik egymást. Köszönnek, viszonylag jó kedélyüek."(41 éves nö, érettségizett)

Interjúalanyaink szerint a településsel való elégedettségük fontos szempontja a község jó infrastrukturális ellátottsága is. Így a település szinte „zöldövezeti kertvárosnak" is tekinthető, ahonnan jellemzően csak a munkahely miatt ingáznak az ott lakók, a többi szolgáltatás már helyben is elérhető.

„Ugyebár van ifjúsági ház, ami nem sok ilyesmi méretü faluban van. Pozitívumként talán még annyit el lehet mondani, hogy boltok, az azért elég sok van. Általában ez nekünk elég, itthon is meg tudja kapni az ember, amit szeretne. Nem feltétlenül kell bemenni például Debrecenbe." (20 éves férfi, technikus)

\section{I.3. TISZABERCEL}

Tiszabercel Szabolcs-Szatmár-Bereg megyében az Ibrányi járásban, Nyíregyházától, a megyeszékhelytől 23 kilométerre fekszik. A település maga a Tisza bal partján található, de határát majdnem pontosan kettévágja a folyó. Az itt élők többsége mezőgazdálkodással foglalkozik. A gazdálkodás középpontjában a búza, kukorica, napraforgó és a szálastakarmányok termelése áll, az állattartás középpontjában a szarvasmarha, sertés és baromfi. A település honlapján a polgármester arra bíztatja a község iránt érdeklődőt, hogy „látogasson el a semmihez nem hasonlító festői szépségű 


\section{TEMATIKUS TANULMÁNYOK - Községekben élő immobil fiatalok}

berceli Tisza-partra, kóstolja meg az utánozhatatlan berceli halászlevelet vagy válassza rendezvényeink, horgásztavaink egyikét." (Szántó 2018) Ezek alapján a község önkormányzatának vezetője a földrajzi fekvést, a természeti értékeket és a település hagyományait tekinti vonzó tényezőnek.

A településen élők egynegyede (24,7\%), a 2011-es népszámlálási adatok szerint roma nemzetiségúnek vallotta magát.

4. táblázat: Tiszabercel lakónépességének alakulása 1990-2018 között*

\begin{tabular}{|c|c|}
\hline Évszám & Lakónépesség föben \\
\hline 2018 & 1797 \\
\hline 2017 & 1820 \\
\hline 2016 & 1809 \\
\hline 2015 & 1819 \\
\hline 2014 & 1863 \\
\hline 2013 & 1897 \\
\hline 2012 & 1933 \\
\hline 2011 & 1921 \\
\hline 2001 & 2080 \\
\hline 1990 & 2207 \\
\hline
\end{tabular}

*Az adatok a népszámlálás éveit $(2011,2001,1990)$ kivéve január 1-ei állapotot mutatnak. A népszámlálás éveiben az összeírás eszmei időpontjára vonatkoznak.

Forrás: Saját szerkesztés Magyarország helységnévtára 2018. adatai alapján ${ }^{6}$

A lakónépesség adatai az itt élők számának folyamatos csökkenését mutatják, ami kisebb részben az élveszületések és halálozások közötti különbséggel magyarázhatóak, nagyobb részben pedig a negatív vándorlási egyenleggel. Ennek értéke a vizsgált időszakban (2005-2015 között) jelentősen felülmúlja mind az országos, mind pedig a régiós, megyei és járási adatokat is, tekintve, hogy Tiszabercel a rendszerváltás óta lakosságának közel 20\%-át elveszítette. A csökkenésre magyarázatot adhat kedvezőtlen foglalkoztatási helyzete és az itt élők nagyon alacsony, az országos átlag alig felényi jövedelme. A jövedelmi adatok azt is mutatják, hogy bár jelentősen csökkent a településen a munkanélküliek száma, az időközben elhelyezkedettek alacsony presztízsű, rosszul fizetett munkát végeznek, jellemzően közfoglalkoztatottak, közmunkások (Loncsák 2018).

\footnotetext{
${ }^{6} \mathrm{http}: / /$ www.ksh.hu/apps/hntr.telepules?p_lang=HU\&p_id=03850
} 


\section{TEMATIKUS TANULMÁNYOK - KöZségekben élő immobil fiatalok}

\section{3.1. A faluban maradás indokai}

Interjúalanyaink jellemzően három tényezővel magyarázzák, hogy miért nem költöznek el a településről. Az első, leggyakrabban említett ok a kényszer, menne, elköltözne innen, de nem tud, mert itt van háza, itt van ingatlanja, földje, amit nem tud piaci áron értékesíteni, nem tud olyan áron hasznosítani, amivel tovább tudna lépni. A rendszerváltás hátrányosan érintette a települést, hiszen megszűntek a helybeni vagy a közeli alacsony, de biztos jövedelmet nyújtó munkahelyek (tsz, zsákgyár). Az egyre csökkenő elhelyezkedési lehetőségek miatt a fiatalok már nem itt akarnak letelepedni, így egyre nehezebb az itteni ingatlanokat értékesíteni, jó áron eladni.

„Elmennék innen, itt nem lehet megélni, elmennék Nyíregyházára vagy Pestre, vagy Dunántúlra, de nem lehet az itteni házat eladni, nincs semmi értéke. Talán a legnagyobb indok, hogy itt telepedtünk le és nehezen tudnánk kimozdulni, vagy pedig ezt a házat eladni. Ha ezt megfelelő értéken meg tudták volna fizetni, akkor valószínü, hogy az én családom is elindult volna." (59 éves nö, érettségizett)

„Itt van lakásunk. Ezt nem tudjuk eladni.” (42 éves nö, szakmunkás)

A második ok a munkahellyel kapcsolatos, itt van olyan munkája, amit szeret, ami szakmájának, végzettségének megfelel, emiatt nem megy el innen.

„A település egy szép hely. Szeretek itt lakni. Kulturált, rendben tartott. A munkahelyem ide köt, valamilyen oknál fogva, ami egy kicsit még bővebb is, mert máshová is kell járni, nagyon szeretem csinálni. A hobbijaim is ide kötnek a környékre, a halászat, vadászat. És ezért ez nekem fontos." (41 éves férfi, szakmunkás)

„Hogy itt nôtttem fel, az nagyon ide köt, hogy itt dolgozom, jó munkám van itt helyben, itt a családom. Amúgy meg biztos, hogy nem maradnék itt." (21 éves férfi, érettségizett, egyetemista)

A harmadik, hogy a város könnyủ elérhetősége kombinálható a falusi élet előnyeivel, a csenddel, a nyugalommal, a természet szépségével, a szabadsággal.

„Hát azért jó itt lakni, mert csendes környék, nagyon közel van a Tisza, amit én nagyon szeretek. Tehát mi itt nőttünk fel, szerintem a nővéremék nevében is beszélhetek, hogy a Tisza-parton gyüjtöttünk bogarakat, növényeket és nagyon a szívünkhöz nött. Belénk, belénk égett ez a vidékszeretet. Úgyhogy én ezért szeretem Tiszabercelt, mert megmaradt ez a kis csöndes falu, ami volt, 


\section{TEMATIKUS TANULMÁNYOK - Községekben élő immobil fiatalok}

mikor még gyerek voltam. Az itteni települések viszonylag hasonlóak, de számomra az itt megélt élmények miatt kedves ez a falu. Tehát csendes, békés környék, viszonylag közel van a város, olyan 35 km, tehát annyira nem nagy távolság, könnyü bejárni." (24 éves nő, egyetemet végzett)

\section{I.3.2. Taszító tényezők, ami miatt el akarnak költözni}

A legtöbben a munkalehetőség hiánya miatt mennének el a településről. Itt helyben esélyük sincs számukra, végzettségüknek, szakmájuknak megfelelő munkát találni, karriert építeni. A településen jellemzően csak az önkormányzatnál, néhány helyi vállalkozónál tudnak elhelyezkedni vagy marad a rosszul fizetett közmunka.

„A gyerekek menjenek hát, jó messzire innen, mert itt nem sokjövőjük van.” (42 éves nö, szakmunkás)

„Ha van valakinek egy csepp esze, akkor nem marad itt. Mivel, hogy munkahelyet nem nagyon tud itt keríteni. Mert most az, hogy bejár Nyíregyházára, akkor minek a család? Mert, mikor elmegy hajnal van, este pedig későn ér haza." (59 éves nő, érettségizett)

Több válaszadónk is említi a romák magas arányát, ami miatt nem szeret itt lakni.

„Sajnos hal ki az idősebb korosztály, meg a lakásokat megveszik a bekerültek, meg a kisebbség, végül is kimondhatom ezt. Mert egyre jobban a kisebbség fog érvényesülni, és ez már most kezd látszani a település képén is, mivel a szépen felépített házakat, az idősek házát megkapják CSOK-on keresztül, szülik a gyerekeket és utána gyönyörüen lelakják. Aztán így a falu képét is rombolják." (59 éves nö, érettségizett)

„De amúgy a települést nem nagyon szeretem, mert...hát sok a kisebbségi érzetü ember, és az rontja az egész községnek a látképét." (21 éves férfi érettségizett, egyetemista)

\section{I.4. KISGYŐR}

Kisgyőr Borsod-Abaúj-Zemplén megyében, Miskolctól 16 kilométerre, délnyugatra, a Bükk-hegység egyik völgykatlanában fekszik. A községet észak és nyugat felől a Bükk hat-hétszáz méter magas nyúlványai, dél és kelet felől alacsonyabb csúcsok és dombok veszik körül. A község egy része a Bükki Nemzeti Park_területén helyezkedik el. 


\section{TEMATIKUS TANULMÁNYOK - Községekben élő immobil fiatalok}

A hegyoldalakat erdő borítja. Sem a községben, sem a környékén nincs ipari tevékenység. Ezért szinte zavartalan a magaslati zöld övezet ősi, természetes állapota. A községet övező hegyek déli lejtőin szőlőskertek sokféle gyümölcsfával keverednek.

A faluról megjelent könyvben a következő olvasható. „A község 1600 főt meghaladó lakossága folyamatosan növekszik, mely annak is betudható, hogy itt minden nyugalmat sugároz. A küzdelmes múltat kárpótolja, hogy a Bükki Nemzeti Park ölelésében csak erősödik az itt lakók hite: jó itt élni!" (Kékedi 2018)

5. táblázat: Kisgyőr lakónépességének alakulása 1990-2018 között*

\begin{tabular}{|c|c|}
\hline Évszám & Lakónépesség föben \\
\hline 2018 & 1655 \\
\hline 2017 & 1690 \\
\hline 2016 & 1677 \\
\hline 2015 & 1680 \\
\hline 2014 & 1675 \\
\hline 2013 & 1664 \\
\hline 2012 & 1663 \\
\hline 2011 & 1670 \\
\hline 2001 & 1624 \\
\hline 1990 & 1572 \\
\hline
\end{tabular}

*Az adatok január 1-re vonatkoznak, kivéve a népszámlálási (1990, 2001, 2011-es) adatokat, amelyek a népszámlálás eszmei időpontjában rögzítik a lakónépességet.

Forrás: Saját szerkesztés Magyarország helységnévtára 2018 adatai alapján ${ }^{7}$

A lakónépességre vonatkozó adatok tendenciaszerú népességváltozást nem mutatnak. 1990-hez képest közel száz fővel nőtt az itt élők száma. Az évenkénti eltérések fóként a születések és a halálozások alakulásának ingadozásával magyarázhatóak. A település vándorlási egyenlege pozitív. Munkanélküliségre vonatkozó mutatói a megyei értéknél alacsonyabbak. Különösen kedvezőek a pályakezdő munkanélküliségre és a tartósan munka nélkül lévőkre vonatkozó értékek. Ezek tendenciája megegyezik a közmunkaprogramok indításával, így valószínűsíthető, hogy a pozitív változások a helyben meghirdetett közmunkaprogramokkal állnak összefüggésben. Erre az interjúkban is utalás történik (Loncsák 2018).

„Korábban nagyon sokat eljárták Miskolcra dolgozni, nagyon sok embernek adtak munkát az ottani gyárak. Ma kb. az itt élók egyharmada tud helyben dolgozni, fóként közmunkán." (22 éves férfi, érettségizett)

\footnotetext{
${ }^{7}$ http://www.ksh.hu/apps/hntr.telepules?p_lang=HU\&p_id=22840
} 


\section{TEMATIKUS TANULMÁNYOK - Községekben élő immobil fiatalok}

\section{I.4.1. A faluban maradás indokai}

Kisgyőr honlapján hosszan olvashatunk a község kedvező földrajzi adottságairól, természeti értékeiről, szépségeiről. A polgármester ezen túl a nyugodt, biztonságos légkört tartja a település fontos ismérvének „Itt mindenki otthon érzi magát.”

Felhívja a figyelmet továbbá arra is, hogy a „történelem, a hagyomány, a kultúra megannyi arca jelen van, a település védjegyévé váltak a faragott köztéri alkotások." (Kékedi 2018)

Valamennyi interjúalany a polgármesterhez hasonlóan a természeti környezetet emelte ki, ezt tartja a település legfontosabb értékének.

„A falu elhelyezkedése nagyon jó. A hegyek engem mindig is vonzottak, meg, ha bárhová mennék is, szerintem csak hegyes helyre mennék." (21 éves férfi, középiskolai végzettség)

„Szebb is, meg azért, mer itt jobb a levegő. Az erdő, az erdei levegő itt természetes." (44 éves nö, 8 ált. iskolai végzettség)

„És ez ugye egy gyönyörü üdülőrész, ahol ők vannak, és tulajdonképpen egész évben úgy érezzük magunkat, mintha nyaralnának." (19 éves férfi, érettségizett)

Még a környező településekkel összehasonlítva is kedvezőbbnek ítélik meg Kisgyőr földrajzi fekvését, természeti értékeit.

„Szerintem Kisgyőr a legszebb a három falu közül.” (25 éves nö, szakközépiskolai végzettség)

„Szerintem Kisgyőr szebb az biztos. És hát nem tudom, szerintem barátságosabbak az emberek itt." (53 éves nö, szakmunkás)

De büszkék az épített környezetre is.

„Szép a falunk, hát például, amik a fafaragó táborban készülnek dolgok: a golgota például, vagy eleve, ha csak a buszmegállókat már megnézzük, mert onnan indul minden, és tényleg nagyon szép." (19 éves férfi, érettségizett)

Válaszadóink a település zsákfalu jellegét előnyként értelmezik, csendesebbnek, nyugodtabbnak, biztonságosabbnak tartják emiatt a községet.

„Nem olyan harsány, mint egy átjáró falu. Nincs átmenő forgalom, csendesebb, nyugodtabb, biztonságosabb." (57 éves nő, érettségizett) 


\section{TEMATIKUS TANULMÁNYOK - KöZségekben élő immobil fiatalok} kintik.

A helyben vagy közelben lévő munkalehetőséget is marasztaló hatásúnak te„Ameddig a munkakörömben találok itt vagy a közelben lehetőséget, addig nem szeretnék elmenni." (22 éves férfi, érettségizett)

A megkérdezettek ugyanakkor azt is tapasztalják, hogy a kilencvenes évekhez képest csökkent az ingázók száma. Ennek legfontosabb oka a rendszerváltás időszakában bekövetkezett gazdaságszerkezeti átalakulás, amely elsőként hátrányosan a Borsod megyei térséget érintette.

„Én szerintem régen jobban eljártak. Akkor még biztosítva volt. Akkor még tudták, hogy elmennek a gyárba és akkor még 10 évig ott lesznek. Hát ez így volt kilencven-kilencvenötig. Ez így volt, mert már mikor én is visszamentem a második gyerekkel dolgozni, akkor már a céget szétszedték. Akkor már kezdődött ez a huzakodás. Az volt a biztos, akkor bentre jártak a cementgyárba, akkor úgy álltunk a buszon, mint a heringek, hazafele is. Most meg üres a busz szinte, megy a déli vagy a fél egyes, hát reggel vannak a tanulók és ennyi, inkább itt keresnek az emberek munkát." (53 éves nő, szakmunkás)

„Szerintem 90 után csökkent az innen eljárók száma, mert megszúnt a gyár: a cementgyár, meg a vasgyár, majd szintén elkezdtek az emberek városba menni dolgozni. Több a munkalehetóség most már talán, de föleg itt a faluban. Most fóként közmunkában dolgoznak az emberek, inkább itt és nem járnak el." (57 éves nő, érettségizett)

Azt viszont problémának tekintik, hogy helyben szinte csak alacsony presztízsű és alacsony jövedelmet biztosító közmunkára van lehetőség.

„Én emlékszek rá, hogy 14 éves voltam mikor bekerültem (bejárt középiskolába Miskolcra), kereskedelmibe jártam és voltam gyakorlaton egy maszek boltba és akkor még tele volt a busz. És épp mondom Zolinak (élettársa), a múlt héten hárman voltunk az éfféli buszon. Most mondd már meg! Nem? Most vagyunk itt kétezren és senki? Nagyon elítélem ezt az államot, mert, hogy lehet az, hogy segélymunkával támogassa az embereket?" (39 éves nő, szakmunkás)

A helyben maradás indokaként jelennek meg a falusias életmóddal összefüggő tényezők is. A családi házas építkezés, nagyobb alapterületú ingatlanok, amelyeket nagyobb szabadsággal azonosítanak, de a kert, a szomszédsági kapcsolatok szintén a település mellett szóló érvek. 


\section{TEMATIKUS TANULMÁNYOK - Községekben élő immobil fiatalok}

„Szerintem falun jobb. Városban nem laknák. Jaj, voltam I-nál egy hete lassan, hát azt hittem, hogy sose érek haza. Nagyon nehezen bírtam ki a bérházban, nem bírnám szerintem. Hát úgy tudod esetleg kibírni, hogy elmész dolgozni, aztán hazamész lefekszel, alszol, úgy igen. De úgy, hogy egész nap bent legyél a bérházban, na úgy nem." (44 éves nö, 8 ált. iskolai végzettség)

\section{I.4.2. Taszító tényezők, ami miatt el akarnak költözni}

Egy interjúalany nyilatkozott úgy, hogy biztosan el fog innen költözni, ő jelenleg középiskolás és Budapestre készül jogi egyetemre. Úgy gondolja, hogy a diploma megszerzése után nagyobb lehetősége lesz karrierépítésre a fóvárosban, mint itt a településen.

„Jelenleg a családom köt ide, de egyetemre, Pestre készülök, végzés után nem tervezem, hogy itt maradok, Pesten szeretnék letelepedni. Esetleg időskoromban jönnék vissza a szép környezet miatt, a környezet és az emberek hozzáállása miatt az élethez." (19 éves férfi, érettségizett)

\section{I.5. SZATMÁRCSEKE}

Szatmárcseke község Szabolcs-Szatmár-Bereg megyében, a Fehérgyarmati járásban, a megye keleti részén fekvő Tisza-parti település. Nyíregyházától 94, Vásárosnaménytól 29, Fehérgyarmattól 17 kilométerre található. Mivel minden oldalról folyóvíz veszi körül, ezért a település sokszor szenvedett árvizektől. A táj szépségét éppen hátránya adja, mivel nehezen megközelíthető és iparilag fejletlen, semmilyen nagyüzem, gyár nincs a közelben.

Polgármestere szerint „a történelmi, irodalmi nevezetességein túl a Tisza és az itt élők vendégszeretete vonzza az idelátogatókat. Többféle szálláslehetőség is van a faluban, ahol speciális szatmári ételeket kínálnak." ${ }^{\prime 8}$

Az itt élők mezőgazdasággal, gabona, takarmány és gyümölcs (alma, szilva) termesztéssel foglalkoznak. Temetője nemzeti kegyhely, ami miatt jelentősen megnőtt az ide látogató vendégek aránya, akik többnyire csak néhány órát töltenek a településen.

${ }^{8} \mathrm{http}: / /$ szatmarcseke.hu/index.php/a-telepuelesrl/kozseg-bemutatasa 
www. metszetek.unideb.hu

\section{TEMATIKUS TANULMÁNYOK - Községekben élő immobil fiatalok}

6. táblázat: Szatmárcseke lakónépességének alakulása 1990-2018 között*

\begin{tabular}{|c|c|}
\hline Évszám & Lakónépesség főben \\
\hline 2018 & 1594 \\
\hline 2017 & 1609 \\
\hline 2016 & 1590 \\
\hline 2015 & 1553 \\
\hline 2014 & 1527 \\
\hline 2013 & 1508 \\
\hline 2012 & 1490 \\
\hline 2011 & 1496 \\
\hline 2001 & 1555 \\
\hline 1990 & 1526 \\
\hline
\end{tabular}

*Az adatok a népszámlálás éveit (2011, 2001, 1990) kivéve január 1-ei állapotot mutatnak. A népszámlálás éveiben az összeírás eszmei időpontjára vonatkoznak.

Forrás: Saját szerkesztés Magyarország helységnévtára 2018. adatai alapján ${ }^{9}$

Az itt élők közel egyharmada $(28,8 \%)$ roma nemzetiségűnek tartja magát. Lakónépessége az évenkénti ingadozásokat is figyelembe véve szinte állandónak tekinthető annak ellenére, hogy 2005 és 2015 között - 2014 és 2015 kivételével - a természetes szaporodás értéke negatív volt, azaz a halálozások száma minden évben meghaladta az élveszületésekét. A népesség számának állandóságát a közeli Ukrajnából történő idevándorlás magyarázza. A beköltözők jelentős része Ukrajnában is megtartja lakását, így jellemzően csak időszakosan tartózkodik a településen. Valamennyi munkanélküliségre vonatkozó adata - munkanélküli rátája, tartós munkanélküliek aránya, pályakezdő munkanélküliek aránya - a település kedvezőtlen helyzetét igazolja. Az itt lakók az országos jövedelmi átlag feléből kell, hogy megéljenek (Loncsák 2018).

\section{I.5.1. A faluban maradás indokai}

Arra a kérdésre, hogy miért szeretnek a megkérdezettek a településen élni, valamennyien az „itt születtem, itt él a családom” típusú választ adták. A család ugyanakkor nem csak érzelmi támaszt nyújt, hanem fontos segítséget jelent a mindennapokban, a gyereknevelésben, házépítésben.

\footnotetext{
${ }^{9}$ http://www.ksh.hu/apps/hntr.telepules?p_lang=HU\&p_id=31237
} 


\section{TEMATIKUS TANULMÁNYOK - Községekben élő immobil fiatalok}

„Anyuék mindenben segítenek, a lányom miatt maradok itt, ha elmennék, nem lenne kire bízni." (25 éves nö, 8 ált. iskolai végzettség)

„Ameddig felépül a fiam háza, addig nálunk laknak.” (57 éves nő, szakközépiskolai érettségi)

„Itt van mindenkim, aki segíteni tud.” (25 éves nő, érettségizett)

Települési előnyként valamennyi interjúalanyunk megfogalmazta a falusi lét pozitívumai közül azt, hogy itt összetartóbbak az emberek, jobban odafigyelnek egymásra, nem közömbösek a másik problémája iránt. Ha már nincs valós alternatíva a mobilitásra, akkor olyan helyen akarnak élni, ahol jól érzik magukat. Ez a szubjektív szempont természetesen már csak akkor számít, ha valóban nincs realitása az elköltözésnek.

„Segítőkészebbek itt az emberek, mivel itt élek az itteni embereket ismerem leginkább, a más falubeliek inkább közömbösek az emberrel, akár össze is súgnak az ember háta mögött."(22 éves nő, szakmunkás)

„Úgy veszem észre, itt jobban összetartanak az emberek, jobban segítenek a másiknak." (22 éves nö, érettségizett)

„Itt jobban összetartanak. Mindenki segít mindenki máson. Épp figyeltem, hogy máshol nem annyira összetartóak. Föleg Vecsés környékén, ahonnan származom. Mindenki csak magával foglalkozik, maga környezetével." (57 éves nö, szakközépiskolai érettségizett)

„Jó itt lakni. Nem az, hogy megszokás, mert nem megszokásból, hanem jó a falu közössége, meglehet „velük” egyezni, beszélni, egymás iránt érdeklődnek, összetartóak." (25 éves nö, érettségizett)

További racionális érvként jelenik meg a helyben való munkalehetőséggel való megelégedettség. Egyik interjúalanyunk gyerekei helyben nyitottak éttermet, így érthető, hogy a családból mindenki hosszú távon a településen képzeli el a jövőjét.

„Én úgy veszem észre, a fiatalok szeretnének itt maradni és maradnak is, akik elmentek azokból is sokan visszajönnek otthonteremtésként, ide a faluba. Vállalkozónak kell lenni vagy marad a közmunka." (57 éves nő, szakközépiskolai érettségi) 


\section{TEMATIKUS TANULMÁNYOK - Községekben élő immobil fiatalok}

„Teljesen végleges döntés, hogy itt maradok. Szeretnék családot alapítani, letelepedni, és a munkámat is itt végezni." (22 éves nö, érettségizett)

A szatmárcsekei válaszokban is megjelenik a kényszerből való immobilitás, mely szerint nincs reális alternatívája annak, hogy a településről valaha is el tudnának költözni. Nem tudják az ingatlant értékesíteni, így tulajdonképpen ide vannak kötve. Főként a szülői generáció válaszaiban jelennek meg ezek az érvek.

„Itt vettünk házat, itt telepedtünk le. Ház miatt, de tényleg csak a ház miatt vagyunk itt, mert eladni nem tudnánk, hát ez a legfőbb szempont, hogy itt élünk." (24 éves nö, érettségizett)

„Nincs semmi itt, a fiatal, ha teheti, innen elmegy, ha nem akar gazdálkodni, mert itt falun csak a gazdálkodásnak van jövője, de nem úgy támogatja ezt az állam, ahogy kéne. Nem szerettem volna, ha Csekébe marad egy sem. Én mindig arra kértem őket, hogy a csekei táblát csak akkor lássátok, mikor engem jöttök megnézni. Mi már maradunk, mert a ház ideköt minket, de ők csak menjenek innen." (57 éves nö, érettségizett)

„Áhh nem, már mi itt maradtunk, itt a fiatal, ők mehetnek. Muszájság, ez van, ezt kell szeretni, a gyermekeinek nem ezt gondolja az ember, ők csak menjek, arra amerre tudnak. Ne maradjanak itt." (43 éves nő, 8 ált. iskolai végzettség)

\section{I.5.2. Taszító tényező, ami miatt el akarnak költözni}

A legtöbben taszító tényezőként a helybeni munkalehetőségek hiányát említik.

„A régi munka megszünt és munkanélküliség van. Felbomlasztották a tsz-t, az állami gazdaságot, az építőipari szövetkezetet, semmiféle munkalehetôség nincs, csak a helyi önkormányzatnál a közmunka, mert semmi nincs. Régen faipar volt, bútorelemeket gyártottak, raklapokat gyártottak, parkettákat, itt a faluban a tsz-nél. A tsz-nél juhászat volt, szarvasmarha telep, minden. Most nincs itt semmi, ezért kell innen elmenni a fiataloknak." (57 éves nö, érettségizett)

A válaszokból az derül ki, hogy nincs konfliktus abból, hogy a településen magas a roma népesség aránya, ez sem vonzó, sem taszító tényezőként nem jelenik meg. Ugyancsak nem említik megkérdezetteink a települési hagyományokat és a falusi turizmus adta lehetőségeket sem. 


\section{TEMATIKUS TANULMÁNYOK - Községekben élő immobil fiatalok}

\section{I.6. NAGYKEREKI}

Nagykereki község Hajdú-Bihar megyében, a Berettyóújfalui járásban, Románia határától kb. 10 kilométerre található. A polgármester szerint a település nagy előnye falusi környezete (Zilai 2018). Nagykereki egyike a bihari térség gazdaságilag, társadalmilag hátrányos helyzetű településének. Hátránya a falu elhelyezkedéséből, a lakosság alacsony iskolai végzettségéből, rossz infrastruktúrájából fakad.

A településen a legjelentősebb foglalkoztató az önkormányzat, ipari tevékenység nincs a területen. A lakosok alkalmi munkából, mezőgazdaságból, kisebb mértékben vállalkozásokból élnek. 16 vállalkozó él a településen. Az alacsony jövedelműek bevételének számottevő része szociális ellátásból származik. A településen magas az alacsony iskolai végzettségú roma lakosság aránya, bár a 2011-es népszámlálási adatok szerint az itt élők 4,9\%-a tekintette magát romának. A polgármester szerint arányuk jóval magasabb (Nagykereki esélyegyenlőségi terve 2018-2022). A település olyan „elmaradt kistérségi falu”, ahonnan a városi munkalehetőségek, a városi szolgáltatások egyrészt a távolság, másrészt a rossz közlekedés miatt nehezen érhetőek le. Az alacsony jövedelmek miatt a saját gépkocsi inkább csak álom, és ha utazni kell, marad a lassú és ritka buszjárat.

7. táblázat: Nagykereki lakónépességének alakulása 1990-2018 között*

\begin{tabular}{|c|c|}
\hline Évszám & Lakónépesség föben \\
\hline 2018 & 1350 \\
\hline 2017 & 1371 \\
\hline 2016 & 1369 \\
\hline 2015 & 1378 \\
\hline 2014 & 1364 \\
\hline 2013 & 1349 \\
\hline 2012 & 1294 \\
\hline 2011 & 1263 \\
\hline 2001 & 1381 \\
\hline 1990 & 1327 \\
\hline
\end{tabular}

*Az adatok a népszámlálás éveit (2011, 2001,1990) kivéve január 1-ei állapotot mutatnak. A népszámlálás éveiben az összeírás eszmei időpontjára vonatkoznak.

Forrás: Saját szerkesztés Magyarország helységnévtára 2018. adatai alapján ${ }^{10}$

A település lakónépessége viszonylag állandó. Az ingadozások oka elsősorban a román állampolgárok lakásvásárlásával indokolható. Mivel a település a határhoz

${ }^{10}$ http://www.ksh.hu/apps/hntr.telepules?p_lang=HU\&p_id=08907 


\section{TEMATIKUS TANULMÁNYOK - Községekben élő immobil fiatalok}

nagyon közel van, egyre több román állampolgár vásárol itt olcsón lakást és ingázik Nagyváradra. Ugyanakkor az elvándorlás nagyon jelentős. A települést a negatív vándorlási egyenleg jellemzi. Az elköltözők száma 2013 évet kivéve minden évben meghaladta az ideköltözőkét. 2008-ban négyszer annyian mentek el, mint amennyin jöttek. A születések és a halálozások száma ingadozik, de a természetes szaporodás értéke pozitív. Ennek köszönhetően a település fiatal korstruktúrájú, a 14 éven aluliak aránya meghaladja a 60 éven felüliekét. Az aktív korú népességben magas az inaktívak aránya. A foglalkoztatási adatok azt jelzik, hogy magas a pályakezdő, az 50 éven felüli és a tartósan állásnélküliek száma. A munkanélküliségi ráta az elmúlt időszakban jelentősen csökkent, ami egyértelműen a közfoglalkoztatási programoknak köszönhető. Tulajdonképpen a településen új foglalkoztatásra nincs lehetőség, így marad a közmunka. Az egy főre jutó nettó összjövedelmi értékek is bizonyítják az itt élők hátrányos helyzetét. A negykerekiek az országos érték alig feléből kell, hogy megéljenek, de jövedelmük jelentősen elmarad a megyei, a régióstól és egyharmadnyi távolságra van a járásitól is (Nagykereki esélyegyenlőségi terve 2018-2022).

\section{I.6.1. A faluban maradás indokai}

Nagykereki hátrányos helyzetű település, mindentől távol, munkalehetőség híján, ahol az ott élőknek alacsony a jövedelműk. Erősen hiányos az infrastruktúrája, ritka és lassú a buszközlekedése. Ahogy az egyik interjúalany fogalmazott.

„Ez egy viszonylag rosszabb állapotú falu. Hát, na, sok jó nincs benne, inkább csak negatív értelemben, de ez szerintem egy átlagos falu, csóró falu. Ez itt már egy világvégi falu." (23 éves férfi, 8 ált. iskolai végzettség)

Ezek a tényezők elég okot jelenthetnek ahhoz, hogy aki teheti, kötözzön el innen. Akkor mi tartja itt a megkérdezetteket?

Tíz nagykereki lakossal készült interjú, életkorúk kivételével nagyon homogén csoportot alkotnak. Valamennyien alacsony iskolai végzettségűek, szakmával nem rendelkeznek, ha igen, akkor nem a szakmájukban dolgoznak. Közmunka vagy nagyon alacsony presztízsű munka (segéd vagy alkalmi munkák) révén jutnak jövedelemhez. Közös bennük az is, hogy nem tudatos vagy szándékolt döntésük az, hogy itt maradjanak. Nincs reális esélyük arra, hogy innen elköltözzenek.

„Mert szegény vagyok, nincs rá lehetőségem, azért maradtam itt szó szerint. Ha lenne rá lehetôségem, már elmennék innen egy másik faluba, ahol lenne munkalehetőségem vagy jobban segítenének a polgármesteri hivatalnál is, de itt segítséget nem kapok senkitól. Nekem egyáltalán nem jó itt lakni. Munkalehetőség nincs, közmunkából élek, amit nagyon keveslek, ötvenháromezer 


\section{TEMATIKUS TANULMÁNYOK - Községekben élő immobil fiatalok}

forint, sok a tartozásom, nem tudok megélni abból jó formán.” (57 éves nő, 8 ált. iskolai végzettség)

„Egy az, hogy még mindig itt lakok, mert mennék innen kézzel-lábbal.” (23 éves nő, szakmunkás)

„Persze elmennék én is, ha lesz, ha lenne annyi pénzem, valahol másutt vennék egy házat és odaköltöznék a párommal.” (25 éves nö, 8 ált. iskolai végzettség

Az interjúkban közös továbbá az is, hogy a megkérdezettek jelentős része nem itt született, már az ideköltözés is egyfajta mobilitási kudarc, mobilitási kudarcként értelmezhető immobilitás, végállomásnak tekinthető. Jellemzően valamilyen probléma, nehézség miatt költöztek ide Budapestről, Debrecenből vagy más városból annak reményében, hogy ez kisebb falu, itt olcsóbb a lakás, könnyebb az élet, itt élő családjuk majd segíti újrakezdésüket.

„Erre csak azt tudnám mondani, hogy a kezdet kezdetén, anno annak idején, amikor ide letelepedtünk, Debrecenből jöttünk, akkor még itt másabb volt a helyzet, annyival, hogy nekem is volt egy munkahelyem. Ez a munkahely idővel sajnos megszűnt, én közmunkás lettem ugyan úgy, mint a feleségem és ez egyre rosszabb lett, egyre rosszabb. És sajnos még azt kell mondanom, hogy 48 évesen nem tehetem meg már azt a feleségemmel, hogy elmenjünk mi is a Dunántúlra vagy akármilyen munkalehetőséget nézni." (48 éves férfi, 8 ált. iskolai végzettség)

„Én férjemmel jöttem ide, én budapesti lakos voltam, idevalósi a férjem Nagykerekibe. Hazajöttünk Nagykerekibe és itt alapítottuk meg a családomat, többi gyerekemet. Kettő született Budapesten és itt élünk. Hát igen, sajnos közmunkás vagyok, de hát nincs mit tenni." (43 éves nő, 8 ált. iskolai végzettség)

„Hát édesanyámnak, a párjának a szülei miatt költöztünk ide és emiatt itt is ragadtunk." (25 éves nö, 8 ált. iskolai végzettség)

Az ideköltözés, az itt maradás kényszerét magyarázzák interjúalanyaink a családdal, szülőkkel való törődéssel is. Mennének, költöznének innen, de szüleikkel nem tehetik meg, hogy magukra hagyják őket.

„A párommal, azért költöztünk ide végül is, mert a szülei idősek voltak és betegségük miatt, de már mind a kettő elhunyt. Amikor megismerkedtünk, már 


\section{TEMATIKUS TANULMÁNYOK - KöZségekben élő immobil fiatalok}

akkor megbeszéltük, hogy ha bárkivel bármi baj lesz, mi itt maradunk." (49 éves nö, 8 ált. iskolai végzettség)

„Janinak a mamája itt lakott és beteg volt és itt kelletett maradni, pedig lett volna lehetöség. Pestre is menni, lett is volna munka akkor Janinak ottan Most már lehetőség sincs, megszoktam, hogy itt maradjunk." (43 éves nő, 8 ált. iskolai végzettség)

\section{I.7. PASZAB}

Paszab község az Észak-Alföld régióban, az Ibrányi járásban, Szabolcs-Szatmár-Bereg megye északi peremén, a Tisza és a Lónyai-csatorna által határolt Rétköz területén, a megyeszékhelytől, Nyíregyházától kb. 25 km-re fekszik. A község Tokaj és Nyíregyháza felől közúton könnyen megközelíthető.

8. táblázat: Paszab lakónépességének alakulása 1990-2018 között*

\begin{tabular}{|c|c|}
\hline Évszám & Lakónépesség főben \\
\hline 2018 & 1177 \\
\hline 2017 & 1218 \\
\hline 2016 & 1243 \\
\hline 2015 & 1232 \\
\hline 2014 & 1268 \\
\hline 2013 & 1273 \\
\hline 2012 & 1252 \\
\hline 2011 & 1259 \\
\hline 2001 & 1333 \\
\hline 1990 & 1214 \\
\hline
\end{tabular}

*Az adatok a népszámlálás éveit (2011, 2001, 1990) kivéve január 1-ei állapotot mutatnak. A népszámlálás éveiben az összeírás eszmei időpontjára vonatkoznak.

Forrás: Saját szerkesztés Magyarország helységnévtára 2018. adatai alapján ${ }^{11}$

A népességszámot tekintve a rendszerváltást követően 2001-ig nőtt a településen élők száma, majd 2001-től folyamatos csökkenés tapasztalható. A 2018-as adatok szerint ma kevesebben laknak Paszabon, mint 1990-ben. Népességfogyásának legfontosabb oka az elvándorlás. Vándorlási egyenlege 2007-től negatív, a legkedvezőtlenebb értéket 2014-ben (mínusz 39 ezreléket) mérték. Az adatok azt igazolják,

${ }^{11}$ http://www.ksh.hu/apps/hntr.telepules?p_lang=HU\&p_id=31972 


\section{TEMATIKUS TANULMÁNYOK - KöZségekben élő immobil fiatalok}

hogy a megyei, de még a járásban tapasztalt munkanélküliségi mutatóknál is kedvezőtlenebb a paszabi helyzet. A tartós munkanélküliek és a pályakezdő állásnélküliek arányát tekintve még az országos és a megyei értéknél is rosszabb a helyzete. Az egy lakosra jutó nettó jövedelem adatai szerint, az itt élők az országos átlag kb. feléből kell, hogy megéljenek. De kevesebbet keresnek itt, mint a megyében vagy az Ibrányi járásban. Ezek az adatok egyértelműen igazolják a településről való elköltözés indokoltságát (Loncsák 2018).

\section{I.7.1. A faluban maradás indokai}

A polgármester szerint a „település jelene, teljes infrastruktúrája, saját újságja, magas színvonalú oktatása, egészségügyi és szociális ellátó rendszere mind azzal a reménnyel kecsegtet, hogy érdemes és kell is jövőnkbe vetett hittel tekintenünk előre." (Tajthy 2018)

Múködik a településen orvosi rendelő, web-es orvosi tanácsadás, postahivatal, gyógyszertár. Valamennyi intézmény a település Fő utcáján, könnyen megközelíthetően helyezkedik el. 2007 szeptemberétől az általános iskola és óvoda az Árpád Fejedelem Általános Iskola, Óvoda, Alapfokú Művészetoktatási Intézmény és Egységes Pedagógiai Szakszolgálat tagintézményeként múködik és pályázatot írtak ki bölcsőde építésére is.

A honlap szerint a település infrastruktúráját tekintve szinte teljes az ellátottság, valamennyi út portalanított aszfaltút Paszabon. Az internet, kábeltelevíziós és telefonhálózat kiépített, a szennyvíz, az ivóvíz és az elektromos áramellátottság 100, a gázhálózat kb. 90\%-os.

A lakosság foglalkoztatását helyben a közintézmények oldják meg, illetve az egyéni vállalkozások, valamint egy-két nagyobb gazdasági vállalkozás. Ezen túl a lakosság munkaképes részének jelentős része a megyeszékhelyre, Nyíregyházára jár dolgozni. Tehát a polgármester a megyeszékhelyhez való közelséget, a jó infrastruktúrát, alapintézményekkel való ellátottságot és a település hagyományait (paszabi szőttes) sorolja vonzó tényezőként (Településünkről). ${ }^{12}$

A „Miért jó itt lakni?” kérdésre a megkérdezettek többsége a „nem jó itt lakni” választ fogalmazta meg. Amit a településen ennek ellenére jónak tartottak „csendes, nyugodt hely, a többi településhez viszonyítottan is csendes." (21 éves nő, 8 ált. iskolai végzettség)

Egy válaszadó mondta, hogy itt van jól fizető, biztos megélhetést jelentő munkahelye. Többen kiemelték, hogy „itt mindenki ismer mindenkit, tehát könnyebb segítséget kapni és ügyet intézni." (62 éves nö, 8 ált. iskolai végzettség)

\footnotetext{
${ }^{12}$ https://www.paszab.hu/node/3
} 


\section{TEMATIKUS TANULMÁNYOK - Községekben élő immobil fiatalok}

Egyetlen válaszadó sem említette a megyeszékhelytől való távolságot, valószínűleg azért, mert mindössze egy megkérdezett volt, aki nem helyben, hanem a közeli kisvárosban dolgozik, így esetükben a megyeszékhely közelsége nem meghatározó a településről alkotott vélemény megfogalmazásánál. Továbbá egyetlen interjúalany sem szólt arról, hogy a település hagyománya számára fontos tényező lenne, esetleg büszke lenne arra.

Jellemző, hogy valamennyi megkérdezett úgy gondolja, annak ellenére, hogy a település infrastruktúrájában a rendszerváltás óta jelentős fejlődés történt (aszfalt utak, víz és szennyvízhálózat, gázhálózat kiépítése, intézmények korszerűsítése) korábban jobb volt itt élni. Ezt pedig a munkalehetőséggel indokolják, a kilencvenes éveket megelőzően helyben több munkalehetőség volt. Mivel jellemzően mezőgazdasággal foglalkoznak az itt lakók, a helyi termelőszövetkezet folyamatos munkalehetőséget biztosított a paszabiaknak, ami bár mindig alacsony keresetet jelentett, de fixjövedelemnek számított.

„Nincs itt semmi, korábban sem volt nagy lehetőség, de akkor legalább a tszben volt munka." (62 éves nö, 8 ált. iskolai végzettség)

Valamennyi megkérdezett elsősorban érzelmi okokkal, ide kapcsolódó családi kötelékekkel indokolta immobilitását.

„Itt születtem, itt éltem le az életem, itt van mindenkim.” (25 éves nö, érettségizett)

„Itt élnek a szüleim, akik tudnak segíteni a gyermeknevelésben.” (21 éves nö, szakmunkás)

„Itt kaptam szülői segítséggel házat, ami városban megérne 40 milliót, itt 3 milliót sem kapnék érte." (47 éves férfi, szakmunkás)

A saját tulajdonú ingatlan településfüggő értéke meghatározó tényezője a helyben maradásnak. Ezt követően a legtöbb megkérdezett a „másutt sem jobb, itt legalább ismernek" állítással indokolta immobilitását. Annak ellenére, hogy magas az itt élő roma népesség aránya, még a népszámlálási adatok is közel 20\%-os értéket mutatnak, ezt egyetlen válaszadó sem említette sem az itt maradás, sem pedig az elköltözés indokaként (Magyarország helységnévtára 2018. Paszab). ${ }^{13}$

${ }^{13}$ http://www.ksh.hu/apps/hntr.telepules?p_lang=HU\&p_id=31972 


\section{TEMATIKUS TANULMÁNYOK - Községekben élő immobil fiatalok}

\section{I.8. VIZSOLY}

Vizsoly község a Károli Biblia szülőfaluja, Borsod-Abaúj-Zemplén megyében, a Gönci járásban található. A település különleges földrajzi fekvésének köszönhetően 2 különböző földrajzi területről is ideálisan megközelíthető, a 3-as fóúton Miskolc megyeszékhelytől 60, Szikszótól 40, Encstől 15 km-re fekszik, de nagyon könnyen megközelíthető a zempléni településkörből is, hiszen Szerencstől mindössze 25 km-re található. A polgármester a település honlapján érthető módon a község történelmi múltjára, a híres református templomra, az ott megtekinthető eredeti Bibliára, valamint a csodálatos természeti környezetére büszke (Bihi 2018).

9. táblázat: Vizsoly lakónépességének alakulása 1990-2018 között*

\begin{tabular}{|c|c|}
\hline Évszám & Lakónépesség száma föben \\
\hline 2018 & 830 \\
\hline 2017 & 848 \\
\hline 2016 & 848 \\
\hline 2015 & 830 \\
\hline 2014 & 858 \\
\hline 2013 & 867 \\
\hline 2012 & 864 \\
\hline 2011 & 874 \\
\hline 2001 & 934 \\
\hline 1990 & 1011 \\
\hline
\end{tabular}

*Az adatok január 1-ei állapotot mutatnak, kivételek ezek alól a népszámlálás éveinek adatai, amelyek az eszmei állapotra vonatkoznak.

Forrás: Saját szerkesztés Magyarország helységnévtára 2018. adatai alapján ${ }^{14}$

Meglepő, hogy a 2011-es népszámlálás adatai szerint a református templomára híres községben a lakosok 77\%-a római katolikusnak vallotta magát és csak 12\%-a reformátusvallású. Magas a roma népesség aránya is a településen, a legutóbbi népszámlálási adatok szerint az itt élők 33\%-a tekintette magát romának. ${ }^{15}$

A lakónépességet mutató adatok egyértelműen jelzik, hogy a településen élők létszáma a vizsgált időszakban folyamatosan csökkent, közel 20\%-kal kevesebben laknak ma Vizsolyban, mint a rendszerváltás idején. Annak ellenére van ez így, hogy 2005 és 2015 között az élveszületések és a halálozások különbsége - 2014-et kivéve - minden évben pozitív értéket mutatott és jelentősen meghaladta úgy az országos, mint a megyei, régiós és járási értékeket is, tehát nem ezek a tényezők indokolják a

\footnotetext{
${ }^{14}$ http://www.ksh.hu/apps/hntr.telepules?p_lang=HU\&p_id=21087

${ }^{15}$ http://www.ksh.hu/apps/hntr.telepules?p_lang=HU\&p_id=21087
} 


\section{TEMATIKUS TANULMÁNYOK - KöZségekben élő immobil fiatalok}

jelentős népességfogyást. Az elvándorlás a településről jelentős, lényegesen magasabb a térségi, járási értékektól. A népességfogyást a polgármester a település legnagyobb problémájának tartja és megoldására is javaslatot fogalmaz meg.

„A vidéki Magyarország fejlesztésének és megtartó erejének záloga a régi paraszti gazdálkodás visszaállítása. Kapcsolódnia kell a programhoz a turisztikai ágazatnak is, és a kettő kombinációjából lehet ezeket a halálra ítélt településeket újra életképessé tenni. Ha ez mind megvalósul, akkor 4-5 éven belül visszatérhet a vidéki élet vonzereje. Ezt követően talán a fiatalokat is itt lehet tartani, csökken az elvándorlás, a népességfogyás, nő a helyben lakó, dolgozó családok száma." (Bihi 2018)

Tovább elemezve a népességfogyás lehetséges indokait azt kell látni, hogy a munkanélküliségre vonatkozó adatok közel háromszorosát mutatják az országosnak, de meghaladják a régióra, megyére és járásra vonatkozó értékeket is. A tartósan munkanélküliek aránya köszönhetően a település közmunka programjának javult ugyan, de még így is meghaladja a 48\%-ot. Ezek alapján nem meglepő, hogy az egy lakosra jutó nettó jövedelem alig fele a magyarországinak és alatta van a megyei, járási értéknek is. Az elemzett mutatók tehát egyértelműen jelzik a település hátrányos helyzetét (Loncsák 2018).

\section{I.8.1. A faluban maradás indokai}

Hat darab interjú készült Vizsolyon élőkkel, három fiatal és három középkorú válaszolt a kérdésekre. A három fiatal válaszai azért különösen érdekesek, mert valamennyien értelmiségiek vagy rövid időn belül azok lesznek. Mivel a településről főként a fiatalok, ezen belül is a fiatal értelmiségiek költöznek el, illetve iskolájuk befejezése után nem jönnek vissza, ezért fontos az itt maradók immobilitási tényezőinek elemzése. Valamennyien itt születtek, szüleik, családjuk a településen él, ezért elsősorban érzelmileg kötődnek a településhez, ami erősíti a biztonság érzését is.

„Hát itt nőttem fel, gyerekkoromat itt töltöttem. Szeretek itt lenni." (24 éves férfi, diplomás)

„Itt nôttem fel, ismerem az embereket.” (50 éves nō, szakmunkás)

„Hát mindenféleképpen itt maradunk, mert itt vannak a családtagok, férjem is idevalósi, itt vannak a barátaink." (48 éves nő, szakmunkás)

Megjelennek a helyben maradás indokaiként a falusi élet jellemzői, előnyei is. 


\section{TEMATIKUS TANULMÁNYOK - Községekben élő immobil fiatalok}

„Hát, amit már eddig is említettem, hogy sokkal jobban szeretem a nyugodt környezetet. Tehát, ha itt kimegyek, nem az van, hogy a zajos kocsiknak és a szén-dioxidnak az illatát érzem. Valamint az emberek miatt is, én egy barátságos, közvetlen embernek tartom magam és egy faluban sokkal, de sokkal barátságosak az emberek. Sokkal jobban kijövök egy falusival, mint mondjuk egy városival. Nekem az is furcsa, ha találkozok egy városival, hogy egészen más a felfogása, másként látjuk a dolgokat. Ezt tapasztaltam is ugye, mert Nyíregyházán elég sokat szoktam lenni és ez által, így a barátaim által is tehát vannak eltérő nézeteink a jövőt illetően. Így igazából ennyi." (21 éves nő, érettségizett, egyetemista)

„Hát én szeretem az embereket és falun barátságosabbak az emberek.” (48 éves nö, szakmunkás)

A válaszokból jellemzően két racionális indok jelenik meg, mindkettőnek főként gazdasági, jövedelmi gyökerei vannak. Az egyik, hogy itt tud megélni, itt van ingatlana, ezt tudja fenntartani.

„Nincsenek meg azok az anyagi és egyéb lehetőségeim, amivel itt hagynám ezt a környéket Biztos háttér és ennyi." (25 éves férfi, diplomás)

A másik racionális érv munkával kapcsolatos. Helyben van olyan munkája, amivel elégedett, illetve itt kaphat a végzettségének megfelelő állást. Mivel köztisztviselőként, pedagógusként nincs lényeges különbség a városi és a falusi bérek között, de az itteni megélhetési költségek alacsonyabbak, itt van háza, itt él a családja is, így érthető módon marad a szülőkkel, a támogató családdal együtt.

„Visszajöhetnék az iskolába tanítani és így könnyebb lenne, mint idegenek közt elkezdeni a tanítást is, hiszen a volt tanáraim mellett, mint mentorált fejlödhetnék, úgyhogy, meg igazán kényelmes lenne így számomra. Most úgy érzem, biztos vagyok benne, hogy itt maradok." (21 éves nö, érettségizett, egyetemista)

„Megfelelő munkahelyünk van ahhoz, hogy itt élhessünk. Végül is ezek a lényeges okok." (50 éves nö, szakmunkás)

„Én szeretem itt az embereket és szerintem én ezért maradtam itt. Szeretek emberekkel beszélgetni és ez biztos ez így van. És nekem, és a férjemnek is itt van munkája." (48 éves nö, szakmunkás) 


\section{TEMATIKUS TANULMÁNYOK - Községekben élő immobil fiatalok}

\section{I.9. SAJÓGALGÓC}

Sajógalgóc község Borsod-Abaúj-Zemplén megyében, a Kazincbarcikai járásban található. A Sajó bal partján, Kazincbarcikától 10, Miskolctól 35, Ózdtól 30 kilométerre fekszik. „Kazincbarcika és Putnok között hegyekkel körbezárt elnyúló völgyben megbújó kistelepülés. Zsáktelepülés jellege elzártságot jelent, de ugyanakkor ennek is köszönheti azt a falusias varázsát, nyugalmát, csendjét, szépségét, békéjét, amit sikerült megőriznie mind a mai napig, ebben a rohanó, változó mai világban. A település területe gondozott, ápolt. A természettel harmonizáló szemléletnek köszönhetően folyamatosan szépül, épül” olvasható a település honlapján. ${ }^{16}$

Annak ellenére, hogy sem óvodája, sem általános iskolája, sem munkahelyet biztosító üzeme nincs, a honlap szerint „összkomfortos település”, hiszen minden közmű (víz, gáz, villany, szennyvíz, telefon, internet) kiépített és valamennyi útja aszfaltozott.

10. táblázat: Sajógalgóc lakónépességének alakulása 1990-2018 között*

\begin{tabular}{|c|c|}
\hline Évszám & Lakónépesség főben \\
\hline 2018 & 313 \\
\hline 2017 & 336 \\
\hline 2016 & 340 \\
\hline 2015 & 334 \\
\hline 2014 & 338 \\
\hline 2013 & 344 \\
\hline 2012 & 347 \\
\hline 2011 & 352 \\
\hline 2001 & 370 \\
\hline 1990 & 334 \\
\hline
\end{tabular}

*Az adatok a népszámlálás éveit (2011, 2001, 1990) kivéve január 1-ei állapotot mutatnak. A népszámlálás éveiben az összeírás eszmei időpontjára vonatkoznak.

Forrás: Saját szerkesztés Magyarország helységnévtára 2018. adatai alapján ${ }^{17}$

Lakónépességére vonatkozó adatai azt igazolják, hogy a természeti szépség és a jó infrastrukturális feltételek ellenére a település lakossága csökkenő tendenciát mutat. A csökkenés elsősorban az elvándorlásból ered. Vándorlási egyenlege 20052015 között két év kivételével minden évben negatív. Munkanélküliségre vonatkozó adatai az országos átlagtól kedvezőtlenebbek (Loncsák 2018).

\footnotetext{
${ }^{16} \mathrm{http}: / /$ www.sajogalgoc.hu/hu/bemutatkoz\%C3\%A1s

${ }^{17}$ http://www.ksh.hu/apps/hntr.telepules?p_lang=HU\&p_id=10171
} 


\section{TEMATIKUS TANULMÁNYOK - KöZségekben élő immobil fiatalok}

\section{I.9.1. A faluban maradás indokai}

A megkérdezettek valamennyije a település fekvéséből és falusi jellegéből eredő előnyöket emelte ki. Az elzártságból, a zsákfalu jellegből következő csendesség és intimitás fontosnak számít az itt maradásban.

„Hát jó kis falu, olyan kis csendes.” (25 éves nő, érettségizett)

„Sajógalgóc sokkal nyugodtabb, mint a többi falu a környéken." (21 éves férfi, érettségizett)

„Zsákfalu. Nincs átmenő forgalom. Sokkal kevésbé szennyezett a levegō." (44 éves nö, diplomás)

Több interjúalany véleménye szerint a biztonsághoz és a nyugodtsághoz az is hozzájárul, hogy a településen alig él roma. Ennek köszönhetően a vendégek, a turisták is szívesen jönnek ide pihenni.

„A környéken azért vannak olyan etnikai osztályok, akik rontják a közösséget. Viszont Galgóc az teljesen jó." (21 éves férfi, érettségizett)

„Kevés a roma, most így mondanám. Kevés a roma, tehát szívesen járnak ide az emberek még nyaralni is. Van itt két vendégház." (25 éves nö, érettségizett)

„Csendesebb. És kevés az elszegényedett család. Olyan értelemben, hogy nem cigány származású, roma származásúak kevesen vannak." (52 éves nő, érettségizett)

Interjúalanyainknál is megjelennek azok a gazdasági, racionális szempontok, amelyek az olcsóbb megélhetéssel és megfizethető ingatlanokkal kapcsolatosak.

„Vásároltunk itt egy lakást. Tehát már van egy lakás. És akkor olyan állapotú lakást kerestünk, ami le van lakva úgymond. Tehát amit nem fogunk sajnálni szétverni és így a saját igényeinknek megfelelően tudjuk azt felújítani. Hát ugye, mivel anyáék is itt laktak, ide épitkeztek, ezért mi is itt vettünk, ennyire volt pénzünk." (25 éves nö, érettségizett)

„Szeretek itt élni Sajógalgócon, hiszen nem tudom milyen máshol lakni, mert mindig itt laktam. Ezért ez a természetes, ez a jó. A másik ok, hogy nyilván még 
www. metszetek.unideb.hu

\section{TEMATIKUS TANULMÁNYOK - Községekben élő immobil fiatalok}

nincs hova menni, nincsen még saját kis kuckó, itt meg a szüleimnél lakok addig, ameddig nem tudok sajátot venni, addig jó itt." (25 éves nö, szakmunkás)

Továbbá a családi kötelékkel összefüggő érvek is az itt maradás mellett szólnak.

„Itt élnek a szüleim. Ide kötnek az emlékeim. Itt mozgok otthonosan.” (56 éves nő, ált. iskolai végzettség)

„A családom itt van, és ez egy biztos pont.” (21 éves nö, érettségizett, egyetemista)

\section{I.9.2. Taszító tényezók, ami miatt el akarnak költözni}

Ugyanakkor az interjúkból az is kiderül, hogy a fenti, főként érzelmi alapú tényezők nem elég erősek ahhoz, hogy valaki hosszú távon itt maradjon. Több racionális érv szól az elköltözés mellett.

„52 évesen azért eljutottam ide, hogy nem jó itt lakni Galgócon. Először, mondjuk én szerettem gyereknek, mondjuk szabadabb volt az élet, mint bármerre. De 52 évesen eljutottam oda, hogy nem szabad falun maradni. Ha valaki nem teheti meg magának, hogy egy kocsit fenntartson, ami azért elég borsos, akkor minden szempontból csak a hátránya van. Egyedül csak a friss levegö meg a csend, ami valamit ér a faluban, de amúgy semmi más." (52 éves nö, érettségizett)

A fiatalabb interjúalanyaink valamennyije annak ellenére, hogy a falusi életet szereti, a szép környezetet kedveli, nem itt képzeli el az életét.

„Hogy mindentől ennyire messze legyen, ez már luxus, ha az emberek itt élnek.” (21 éves férfi, érettségizett)

Hasonlóan a fiatal interjúalanyainkhoz szüleik is előnyösebbnek tartják a városi életet, egyrészt a karrier, a munkalehetőségek, másrészt az urbanizált lakókörnyezet és a kényelem miatt, hiszen ide egy héten csak egyszer jár orvos, nincs helyben gyógyszertár, óvoda, iskola, bevásárlási lehetőség, korlátozottak a szórakozás, kikapcsolódás formái is.

A gyermekek jellemzően magasabb iskolai végzettséggel, olyan szakmával rendelkeznek, amelyet a településen, de még a környéken sem preferálnak, így az egyéni boldogulásuk szempontjából elképzelhetetlen az itt maradás, ami számukra inkább lenne kudarc, kényszer, ideiglenes megoldás, mint szabad választás. 


\section{TEMATIKUS TANULMÁNYOK - Községekben élő immobil fiatalok}

Az érzelmi alapú érveket, amelyeket a szép környezet, gyermekkori emlékek táplálnak, a szülők időnkénti meglátogatása, a szabadságok itt töltése teljes mértékben kielégíthetik.

„A fiataloknak el kell innen menni, mert nincs itt semmi, itt nem lehet dolgozni, karriert építeni. Én már maradok, mert ebben a korban már hova mennék, de a fiatalok, azok csak menjenek." (56 éves nö, 8 ált. iskolai végzettség)

„A gyerekeknek el kell innen menni, itt nem lehet hosszú távon megélni, munkát vállalni." (50 éves nő, szakmunkás)

„Az szóba került néhányszor, hogy mi lenne, ha elköltöznénk. Heves tiltakozásukat fejezték ki a gyerekeink. Hogy ez szóba sem kerülhet, hogy nekünk mindenképpen itt kell maradni. Még ha ők, a gyerekeink úgy is döntenek, hogy most nem itt élik meg a mindennapjaikat, akkor is, ők vissza szeretnének rendszeresen térni és úgy képzelik el az életüket, hogy máshol élnek, de pihenni majd a családjukkal csak idejönnek vissza." (44 éves nö, diplomás)

\section{Jelentős munkanélküliséggel nem sújtott települések lakónépesség szerinti csökkenő sorrendben}

\section{II.1. JÁSZSZENTANDRÁS}

Jászszentandrás község Jász-Nagykun-Szolnok megyében, a Jászapáti járásban, az Alföld északi részén a Jászságban, Mátraaljához közel, Jászberény vonzáskörzetében, Heves (11 kilométerre) és Jászapáti (10 kilométer) között, Jászberénytől 30 kilométerre található. Mezőgazdasági jellegű község. A lakosság aktív dolgozóinak egy része ingázóként a környék nagyobb településein (Jászberény, Jászfényszaru, Visonta stb.), azok üzemeiben dolgozik.

A 90-es évektől megnőtt a vállalkozók, vállalkozások száma; 2018-ban 33 kereskedelmi, 10 vendéglátó-ipari egység, 71 szolgáltatást végző, 13 ipari tevékenységet folytató, 14 mezőgazdasági vállalkozás és 6 egyéb vállalkozás működik a községben, továbbá 63 mezőgazdasági őstermelő rendelkezik igazolvánnyal. Összesen 210 vállalkozás müködik a községben.

A növénytermesztés a fő mezőgazdasági tevékenysége a településnek, jelentős a gabonaféléken kívül a dinnye-, kukorica-, illetve a szőlő- és gyümölcstermesztés. A külterület jelentős részén erdőgazdálkodás folyik. Állattartás szempontjából a családi gazdálkodásban tenyésztett szarvasmarha, sertés és baromfi a jelentős.

A község infrastruktúrája fejlett, a 31-es számú út jelenti a fö közlekedési irányt, amely összeköti Jászszentandrást Jászapátival. Vasútvonal nem halad át a falun, leg- 


\section{TEMATIKUS TANULMÁNYOK - Községekben élő immobil fiatalok}

közelebbi vasútállomás 10 km-re (Jászapáti) és $11 \mathrm{~km}$-re (Heves) van. A belső utcák 95\%-a szilárd burkolatú. A belterület teljes területén kiépített a villamosenergia, a telefonhálózat, a vezetékes víz és a vezetékes gáz. A legutóbbi fejlesztések során elkészült a szennyvízcsatornázás, és a kábeltelevízió széles sávú internethasználattal. Jászszentandráson a hatvanas években bukkantak a föld mélyében rejlő vastartalmú termálvízre, mely elsősorban mozgásszervi panaszok kezelésére kiváló. ${ }^{18}$

11. táblázat: Jászszentandrás lakónépességének alakulása 1990-2018 között*

\begin{tabular}{|c|c|}
\hline Évszám & Lakónépesség föben \\
\hline 2018 & 2399 \\
\hline 2017 & 2383 \\
\hline 2016 & 2411 \\
\hline 2015 & 2440 \\
\hline 2014 & 2471 \\
\hline 2013 & 2504 \\
\hline 2012 & 2530 \\
\hline 2011 & 2552 \\
\hline 2001 & 2704 \\
\hline 1990 & 3029 \\
\hline
\end{tabular}

* Az adatok a népszámlálás éveit (2011, 2001, 1990) kivéve január 1-ei állapotot mutatnak. A népszámlálás éveiben az összeírás eszmei időpontjára vonatkoznak.

Forrás: Saját szerkesztés Magyarország helységnévtára 2018. adatai alapján ${ }^{19}$

A település lakónépessége folyamatosan csökken. A rendszerváltás óta a község lakónépességének 20\%-át vesztette el. Öregedő korstruktúrájú település, a 60 évesek aránya meghaladja a 30\%-ot. Ebből következik, hogy a halálozások száma jelentősen magasabb, mint az élve születéseké. 2005 és 2015 között a vándorlási egyenlege is három évet kivéve negatív értéket mutatott, ami azt jelzi, hogy a község népességmegtartó ereje gyenge. Foglalkoztatási adatai alapján nem tekinthető munkanélküliséggel jelentősen sújtott településnek, bár munkanélküliségi rátája kedvezőtlenebb az országosnál, de jobb, mint a régiós, a megyei és járási érték. Magas a tartósan állásnélküliek aránya, meghaladja az 50\%-ot. Kedvezőn alakul viszont a pályakezdő munkanélküli aránya, amely egyharmada a régiós értéknek. Bár az egy lakosra jutó nettó összjövedelmi mutatója nem éri el az országos értéket, de megegyezik az Észak-Alföld régióban mért összeggel és jelentősen meghaladja a járás összjövedelmi mutatóját is. A 2011-es népszámlálási adatok szerint roma nemzetiségű nem él a községben (Loncsák 2018).

\footnotetext{
${ }^{18} \mathrm{http}: / /$ www.jaszszentandras.hu/jelen

${ }^{19} \mathrm{http} / / /$ www.ksh.hu/apps/hntr.telepules?p_lang=HU\&p_id=13514
} 


\section{TEMATIKUS TANULMÁNYOK - Községekben élő immobil fiatalok}

\section{II.1.1. A faluban maradás indokai}

Hét darab interjú készült el, valamennyi megkérdezettünk legalább középfokú végzettséggel rendelkezik és főként a környező városokban dolgozik. A legjellemzőbb racionális motívum, az ún. „bejáró racionalizmus”, azaz a könnyen elérhető város, ahol megtalálható a végzettségnek megfelelő munkahely és a falusi életmód előnyeinek ötvöződése. Mivel valamennyi interjúalanynak olyan munkahelye van, amellyel elégedett, így kevésbé számít, hogy az helyben van vagy utazni szükséges hozzá, akár 30 kilométert is.

„Egy csendes kis falu, és végül is városhoz is közel van, például, ami olyan nagyobb város közelünkben, az Jászberény, körülbelül 30 km-re van, ez szerintem pont az a kényelmes távolság. Igazából a csendessége miatt szeretik ezt a falut. Szerintem kevesen is lakunk itt, mindenki ismer már mindenkit és munkát is elég hamar sikerült a környéken találni, meg tudtam is, hogy ebbe a szakirányba fogok tudni a környéken elhelyezkedni, úgyhogy fel sem merült, hogy akkor én innen elköltözzek." (23 éves nö, érettségizett)

„Jászberénybe jártam, ez olyan 30 km-re volt, busszal jártam minden nap, ez körülbelül 45 perces út, körülbelül, tehát egy nap körülbelül 1,5 órát töltöttünk el utazással. Szerintem ez nem egy nagy táv, most már autóval járok, korábban ezt busszal tettem, úgyhogy egyelöre ez a Jászberény távolság maradt meg nekem. Szerintem ez nem vészes, tehát ez a napi, összesen 60 kilométer, tehát megjárom fél óra alatt, körülbelül egy órát töltök utazással egy nap. Szerintem ez nem olyan vészes." (23 éves nó, érettségizett)

„Sok munkahely nincs Szentandráson, de el lehet helyezkedni, sokfelé el lehet helyezkedni, meg azért járnak buszok, tehát aki akar, az el tud helyezkedni. Hát ez jó kis közösség, tehát az emberek is, úgy ahogy jók, sok minden közel van, hiába, hogy azt mondják, hogy kiesik, de akármit könnyen meg tud oldani, tehát bárhova kellett utazni nem kellett órákat várni, könnyen el tudtál intézni bármit Meg tényleg munkalehetöség is volt, azért az ember nem könnyen adja fel az állását, mert utána vagy sikerül, vagy nem." (49 éves nő, 8 ált. iskolai végzettség)

„Nem akarok elmenni innen. Szerintem eléggé barátságosak itt az emberek, úgy gondolom, hogy a kis közösségben sokkal jobban odafigyelnek egymásra, mint mondjuk egy nagyobb városban, és én úgy gondolom, hogy ami szükséges egy család számára, az itt megtalálható. Tehát vannak boltok, üzletek, ruházati üzlet is van, viszonylag a tömegközlekedés is megoldott, a közelben van munkahely, infrastruktúrával lehet, hogy lehetne egy kicsit fejleszteni a dolgo- 


\section{TEMATIKUS TANULMÁNYOK - Községekben élő immobil fiatalok}

kon, de úgy gondolom, hogy így minden megtalálható, ami kell egy hétköznapi ember számára." (24 éves nó, diplomás)

Fontos érv az itt maradás mellett, a település otthonossága, biztonsága. Minden megkérdezett az otthonosság és biztonság alapkritériumának azt tartotta, hogy a településen nem élnek romák.

„Én születésem óta itt lakom, ez előny, meg hát az, hogy olyan kis rendezett falu, nincsenek cigányok, ez sokat jelent... Az biztos, hogy a kisebbség az rengeteget jelent, nagyon sokat jelent." (49 éves nö, 8 ált. iskolai végzettség)

„Miért jó itt lakni? Nincs cigány például. Itt nyugodtan ki meri engedni az ember a gyerekeket az utcára a cigányok végett, mert szerintem ez máshol nem nagyon van. Én szeretek itt lenni, mondom a cigányok miatt is, szerintem az itt az első, mondjuk is na, hogy itt nincs cigány, most egy olyan faluban élni szerintem, ahol cigányok vannak, ott nem igazán jó, mert én ismerem fiatalkoromból, hogy kötözködnek és az élő fába is belekötnek." (45 éves nő, szakmunkás)

„A településünkön nem található roma, ez szerintem nagyon nagymértékben befolyásolja az itt lakók életét, mert emiatt nagyon csendes, és nem kell nagyon nagy közbiztonságra törekednünk, mint a környező falukban, például Jászapátin." (24 éves nö, érettségizett)

\section{II.1.2. Taszító tényezők, ami miatt költözni akarnak}

Fiatal megkérdezetteink válaszai azt sejtetik, hogy hosszú távon a munkahelytől teszik függővé mobilitásukat. Egyelőre még gazdasági racionalitási okok miatt maradnak, hisz itt van hol lakni, a család segíti őket, de még nem rendelkeznek olyan tartalékkal, tőkével, aminek segítségével el tudnának indulni. Még pályájuk elején járnak, tapasztalatszerzés érdekében még szívesen maradnak, de későbbi karrierjüket már nem itt képzelik el.

„Hát itt öszintén nem sok minden vár rám ebben a faluban, ez tényleg egy kicsi, meg otthonos, meg minden, de munkalehetöség nincs annyi, és ez a fizetésen is látszik, mert nem fizetik meg úgy az embert, mint pl. Pesten, vagy akár Egerben. Hogy itt maradtam a faluban? Hát tényleg csak a családomat bírom felhozni, csak a barátaimat, ha ôk nem lennénk, akkor semmi okom nem lenne itt maradni, úgyhogy talán még a munkahelyem egyelöre, de szerintem ez a három ok, amiért én itt vagyok. Azt nem mondanám, hogy végleges, mert nem 


\section{TEMATIKUS TANULMÁNYOK - Községekben élő immobil fiatalok}

szeretnék örökre itt maradni, de még szerintem egy jó ideig itt leszek." (24 éves nö, érettségizett)

„Nagyon sokáig szerettem volna kimenni külföldre a tanulmányaim alatt, de aztán végül is mindig úgy adódtak a körülmények, hogy jobb lehetőségeim voltak itthon, így nem mentem ki, de még nincs kizárva a lehetöség. Tehát úgy gondolom, hogy családalapítás elött megyek el, egy kaland is lenne, meg sok tapasztalatot szerezhet az ember külföldön." (24 éves nö, diplomás).

\section{II.2. APAGY}

Apagy község Szabolcs-Szatmár-Bereg megyében, a Nyíregyházi járásban, a megyeszékhelytől mindössze 17 kilométerre fekszik, közlekedése kedvező, megközelíthető a Nyíregyháza - Vásárosnamény főközlekedési úton.

Polgármestere a község honlapján olvasható köszöntőjében a település vonzó tényezői közül kiemeli csendes, nyugodt légkörét, horgásztavát, rendezett környezetét és kiváló infrastruktúráját. Apagy vezetékes gázzal, villannyal, vízzel, szennyvízhálózattal rendelkezik, oktatási és egészségügyi, szociális alapellátása biztosított, a vállalkozások nagy számban vannak itt jelen. Apagyon 85 egyéni vállalkozó dolgozik, a nagyobb vállalkozások száma 18. Jellemző tevékenységeik mezőgazdasági és kereskedelmi vállalkozások, kiskereskedés és szolgáltató jellegű tevékenységek. A településen működik a nagyobb vállalkozások közül zöldség-gyümölcs gyorsfagyasztó hűtőház, léüzem, bútordiszkont, ahol bútorok gyártásával és összeszerelésével is foglalkoznak, van varrodája és péksége is. Apagyon található a Nyíregyházi Mezőgazdasági Szakközépiskola Állattenyésztési Oktató Telepe, amely ökológiai centruma a biogazdálkodás elterjesztésének. Ipari területe lehetőség biztosít új üzemek beindítására, hazai és külföldi cégek letelepedésére. ${ }^{20}$

Lakónépességének alakulása azt igazolja, hogy az elemzett 28 évben - ellentétben a hozzá hasonló nagyságú településekkel - népessége lényegében nem változott, tehát a község népességmegtartó ereje hosszútávon is jó. Az ingadozásokat a születések és halálozások évenkénti eltérései okozzák. Amíg természetes szaporodási mutatói 2005 és 2015 között jellemzően negatívak, addig vándorlási egyenlege a vizsgált időszakban többször volt pozitív.

\footnotetext{
${ }^{20}$ https://apagy.hu/?staffs=a-kallay-csaladrol
} 
www. metszetek.unideb.hu

\section{TEMATIKUS TANULMÁNYOK - Községekben élő immobil fiatalok}

12. táblázat: Apagy lakónépességének alakulása 1990-2018 között*

\begin{tabular}{|c|c|}
\hline Évszám & Lakónépesség főben \\
\hline 2018 & 2340 \\
\hline 2017 & 2333 \\
\hline 2016 & 2320 \\
\hline 2015 & 2309 \\
\hline 2014 & 2281 \\
\hline 2013 & 2279 \\
\hline 2012 & 2288 \\
\hline 2011 & 2284 \\
\hline 2001 & 2363 \\
\hline 1990 & 2318 \\
\hline
\end{tabular}

*Az adatok a népszámlálás éveit $(2011,2001,1990)$ kivéve január 1-jei állapotot mutatnak. A népszámlálás éveiben az összeírás eszmei időpontjára vonatkoznak.

Forrás: Saját szerkesztés Magyarország helységnévtára 2018. adatai alapján ${ }^{21}$

Munkanélküliségre vonatkozó adatai alapján nem tekinthető kedvezőtlen helyzetben lévő településnek. Munkanélküliségi rátája, a tartós munkanélküliek aránya az országos átlagot hozza, de kedvezőbb a régiós, a megyei és a járásban mért értékeknél. Az egy lakosra jutó nettó összjövedelmi adatai alacsonyabbak ugyan, mint az országos átlag, nem érik el a járási értékeket sem, de magasabbak, mint a Szabolcs-Szatmár-Bereg megyében mért jövedelmi értékek (Loncsák 2018). Ahogy a honlapról is olvasható a település kedvező helyzetét két lényeges tényező határozza meg, az első a megyeszékhelyhez való közelsége és jó megközelíthetősége, sűrű buszjárata, másrészt a helyben lévő nagyszámú munkalehetőség. ${ }^{22}$

\section{II.2.1. A faluban maradás indokai}

Négy apagyi lakossal készült interjú. Ők valamennyien a település földrajzi fekvését emelték ki azt, hogy nem egész fél óra alatt elérik Nyíregyházát. Így gyakorlatilag az innen hiányzó munkalehetőségek nem számítanak hátránynak. Szintén nem jelent problémát a szúkebb bolti hálózat sem, mert a napi bejárás alkalmat ad az ottani bevásárlásra is. A tudatos faluban maradás indoka ennél a településnél az, hogy a megyeszékhely könnyen, gyorsan elérhető és ehhez jönnek még a kistelepülés, a falusi élet előnyei is. Ezt Krémer Balázs „alkalmazotti ingázó övezetnek” tekinti (Krémer 2018). Ugyanakkor a mindennapok kényelméhez szükséges intézmények, infra-

\footnotetext{
${ }^{21}$ http://www.ksh.hu/apps/hntr.telepules?p_lang=HU\&p_id=20303

${ }^{22}$ https://apagy.hu/?staffs=a-kallay-csaladrol
} 


\section{TEMATIKUS TANULMÁNYOK - Községekben élő immobil fiatalok}

struktúra helyben is elérhető, hiszen van itt orvosi rendelő, gyógyszertár, bölcsőde, óvoda, általános iskola. Ha szükség van valamilyen speciális gyógyszerre, szakorvosra, középiskolára, akkor is csak napi 1 órát vesz igénybe a közlekedés.

„Hát egyébként Nyíregyháza is közel van, ugye nincs olyan messze. Jó a vonatközlekedés, a busz. Ugye van itt bölcsőde, óvoda, iskola, boltok. Szóval így meg vagyok elégedve így mindennel." (28 éves nö, szakmunkás)

„Én szeretek itt lakni Apagyon, szeretem ezt a községet, na, az, az igazság. Nekem jó itt. Itt megvan minden, gyógyszertár, orvos, bölcsőde, ami meg nincs, azért bemegyünk Nyíregyre, nagyon jó és sürü a buszközlekedés." (49 éves nö, szakmunkás)

A megyeszékhelyhez való közelség miatt az interjút adó szülők azt sem tartják problémának, ha a gyerekeik be szeretnének költözni Nyíregyházára.

„Hozzám közel legyenek. Vagy legalábbis úgy, hogy könnyen megközelíthetőek legyenek. Hogyha segítségre szorulnak, vagy ha már családot alapítanak és jönnek az unokák, akkor azért tudjak, olyan elérhető távolságba, hogy anya tudsz jönni vigyázni a kicsikre? Megyek kisfiam." (41 éves nő, érettségizett)

„Itt szeretném, ha itt laknának Apagyon, de hogyha ők Nyíregyházára szeretnének menni, akkor mennek Nyíregyházára, el tudok én oda is könnyen menni." (49 éves nö, szakmunkás)

Egy interjúalany azért szeret Apagyon élni, mert itt nincsenek romák.

„Hát figyelj! Én azt mondom, hogy - ha ezt így lehet mondani - kisebbség itt a mi falunkban egyáltalán nem is mutatkozik." (20 éves férfi, szakmunkás)

Egy interjúalanyunk a falu nyújtotta ismertséget nemcsak az „egymás segítése”, „odafigyelés a másik problémájára” nézőpontból tartja fontosnak, hanem leendő vállalkozóként üzleti sikereket is ettől remél.

„Vállalkozó szeretnék lenni, itt sokan ismernek, szerintem hívnának sokan, mert ismernek, tudják, hogy milyen vagyok." (18 éves férfi, szakmunkás) 


\section{TEMATIKUS TANULMÁNYOK - KöZségekben élő immobil fiatalok}

\section{II.2.2. Taszító tényezők, ami miatt el akarnak költözni}

Két megkérdezett a falusi élet mások által előnyként tartott „itt mindenki ismer mindenkit" jellemzőjét hátrányként éli meg.

„Hát az emberek, nem mindenkit szeretek, inkább így mondom. Úgy maga a falu az tetszik, az szép, szerintem nagyon sokat fejlődött, viszont elég sok negatív élmény ért itt engem, úgyhogy én nem szeretem ezt a falut. Hát a pletyka leginkább, itt mindenki ismer mindenkit, mindenkiról tud mindenki, aztán az ebből jön a rosszindulat, az irigység, ez mind-mind jellemző itt." (41 éves nő, érettségizett)

„Hát pletykás a falu nagyon.” (18 éves férfi, szakmunkás)

\section{II.3. BERKESZ}

Berkesz község Szabolcs-Szatmár-Bereg megyében, a Kemecsei járásban, Kisvárdától 20, Nyíregyházától 30 kilométerre található, közúton a 4-es fóuton érhető el.

13. táblázat: Berkesz lakónépességének alakulása 1990-2018 között*

\begin{tabular}{|c|c|}
\hline Évszám & Lakónépesség föben \\
\hline 2018 & 866 \\
\hline 2017 & 872 \\
\hline 2016 & 854 \\
\hline 2015 & 834 \\
\hline 2014 & 837 \\
\hline 2013 & 855 \\
\hline 2012 & 888 \\
\hline 2011 & 879 \\
\hline 2001 & 959 \\
\hline 1990 & 1105 \\
\hline
\end{tabular}

* Az adatok a népszámlálás éveit (2011, 2001, 1990) kivéve január 1-ei állapotot mutatnak. A népszámlálás éveiben az összeírás eszmei időpontjára vonatkoznak.

Forrás: Saját szerkesztés Magyarország helységnévtára 2018. adatai alapján ${ }^{23}$

A lakónépesség számának változása egyértelműen igazolja a folyamatos csökkenést, amit egyrészt a természetes szaporodás negatív értékei, másrészt az odaván-

\footnotetext{
${ }^{23}$ http://www.ksh.hu/apps/hntr.telepules?p_lang=HU\&p_id=07472
} 


\section{TEMATIKUS TANULMÁNYOK - Községekben élő immobil fiatalok}

dorlók és az elvándorlók közötti különbségek magyaráznak. A falu csekély népességmegtartó erejét mi sem bizonyítja jobban, minthogy a hetvenes években még több mint 1300 fős lakossága 2018-ra közel egyharmaddal csökkent. A lakosság jövedelme alapján hátrányos helyzetű településnek tekinthető. Az egy főre jutó nettó jövedelem Berkeszen alatta marad az országos és régiós átlagnak, de a megyei értékkel megegyezik és kedvezőbb a Kemecsei járásban mért adatoknál. Munkanélküliségi rátája csak az országosnál magasabb. Kirívóan magas viszont a pályakezdő munkanélküliek aránya a településen. A foglalkoztatásra vonatkozó adataiban bekövetkezett változások jelzik, hogy a községben sokan dolgoznak közfoglalkoztatásban. A helyi munkalehetőségek szűkösek, de a gazdaságilag prosperáló Kisvárdához és a megyeszékhelyhez való közelsége, jó közlekedése miatt elérhető távolságban van elegendő munkahely. A 2011-es népszámlálási adatok szerint az itt élők 8\%-a vallotta magát romának (Loncsák 2018).

\section{II.3. 1. A faluban maradás indokai}

Négy berkeszi lakossal készült interjú. Interjúalanyaink racionális motívumai között megtalálhatóak a Krémer Balázs által „bejáró racionalistaként” definiált indokok, mely szerint a város könnyű és viszonylag gyors elérhetősége kombinálható a falusi élet előnyeivel (Krémer 2018). Ezt mindként fiatal interjúalanyunk megfogalmazta.

„Egy munkahelyet keresni, ezt még nem tudom, hogy mi, hogy hol szeretném szerezni, de viszont szeretnék szerezni egy stabil munkahelyet, ahol jó úgy a fizetés is, meg közel is legyen, az is lényeges, ne kelljen innen több órát utaznom, mert én szeretek itt lakni. Itt falun kedvesebbek, rugalmasabbak az emberek, jobban segítenek azon, aki bajban van. Innen a bejárás még úgy elmegy viszonylag. Meg ugye a barátaim, a családom miatt, így még közel tudok maradni hozzájuk." (21 éves férfi, szakmunkás)

„Én szeretek itt lakni. Pont azért, amit mondtam, hogy csendes, nyugodt, békés. Már csak egy jó állást kell szerezni itt a közelben egy városban." (23 éves nő, érettségi)

Valamennyi megkérdezett a településen született, itt él a családja, itt élnek a rokonai és a barátok. A családi támogatás igénybevétele, mint immobilitási tényező mellett két interjúalanynál megjelennek a szülők, az idősebbek segítésének szempontjai is. 


\section{TEMATIKUS TANULMÁNYOK - Községekben élő immobil fiatalok}

„Szüleink itt vannak, és ha segíteni kell, akkor tudunk segíteni. Nekem is idős szüleim vannak és akkor így segíteni kell, vagy ha betegek, akkor ugye gondozni kell öket és így, itt maradtunk." (46 éves nö, érettségizett)

„Volt egy családi eset, amiatt is úgy voltam... hogy itt kell maradni (az édesapja elhunyt), a családot támogatni." (45 éves nö, érettségizett)

\section{II.3.2. Taszító tényezők, ami miatt el akarnak költözni}

Ezzel szemben az idősebb interjúalanyaink szerint gyerekeik a helybeli munkalehetőségek hiánya miatt csak ideiglenesen fognak itt maradni. Véleményük szerint a bejárás hosszú távon nem kivitelezhető és a városi lét nyújtotta előnyöket nem fogják feladni a most még fontosnak tartott barátokért.

„Szerintem nem nagyon fognak a faluban maradni, mert nekik itt nincs az, az élet. Itt azzal a végzettséggel nem fog tudni elhelyezkedni a lányom sem, ha el is tud, akkor nem annyiért, mint egy városon, egy nagyobb vállalatnál. Hát a fiú meg még nem tudom, hogy most azt mondja, hogy marad, de nem biztos, hogy fog maradni." (45 éves nö, érettségizett)

„Hát így... nem tudom, de szerintem városba fognak menni, mert itt nekik a végzettségükhöz képest nem fognak tudni elhelyezkedni, hiába szeretné az ember, hogy maradjanak itt, hogyha nem fognak keresni, meg ők nem érzik itt jól magukat. Meg ugye csak megszokják a várost, meg ott nagyobb az élet, több lehetöség van, tanfolyamokra, akármire, szórakozásra, mindenhova." (46 éves nö, érettségizett)

\section{II.4. NYÍRKÉRCS}

Nyírkércs Szabolcs-Szatmár-Bereg megyében, a Baktalórántházai járásban Nyíregyházától 36 kilométerre lévő település. Saját vasútállomása nincs. A település az alapvető oktatási és szociális ellátást biztosítani tudja az ott élők számára. Erdősültsége meghaladja az országos átlagot. A község lakosságának megélhetését az itt működő Baromfi-Coop Kft, mint mezőgazdasági középvállalkozás segíti, mely felvásárolja a község őstermelőitől a baromfit és helyben munkalehetőséget is biztosít. Néhány kisvállalkozás is van a faluban, melyek főleg mezőgazdasági szolgáltatást végeznek. ${ }^{24}$

\footnotetext{
${ }^{24}$ http://nyirkercs.hu/bemutatkozas
} 
www. metszetek.unideb.hu

\section{TEMATIKUS TANULMÁNYOK - Községekben élő immobil fiatalok}

14. táblázat: Nyírkércs lakónépességének alakulása 1990-2018 között*

\begin{tabular}{|c|c|}
\hline Évszám & Lakónépesség fóben \\
\hline 2018 & 799 \\
\hline 2017 & 797 \\
\hline 2016 & 793 \\
\hline 2015 & 804 \\
\hline 2014 & 806 \\
\hline 2013 & 826 \\
\hline 2012 & 817 \\
\hline 2011 & 821 \\
\hline 2001 & 856 \\
\hline 1990 & 849 \\
\hline
\end{tabular}

* Az adatok a népszámlálás éveit $(2011,2001,1990)$ kivéve január 1-jei állapotot mutatnak. A népszámlálás éveiben az összeírás eszmei időpontjára vonatkoznak.

Forrás: Saját szerkesztés Magyarország helységnévtára 2018. adatai alapján ${ }^{25}$

Népessége lassan fogyó, a vizsgált 28 alatt 50 fővel csökkent (6\%). A csökkenés egyrészt a természetes szaporodás és a vándorlási egyenleg jellemzően negatív értékével magyarázható. Idősödő település 2015-ös adatok szerint az itt élők 40\%-a 60 év feletti, ami magyarázza az alacsony születési és magas halálozási arányt (2015ben 3 születés és 14 halálesetet volt a településen). Foglalkoztatási adatai azt igazolják, hogy nem tartozik a jelentős munkanélküliséggel sújtott települések közé. Munkanélküli rátája bár az országos értéknél magasabb, a régió és a megyei érték közelében van, viszont alacsonyabb a járásban tapasztaltakétól. Magas viszont a tartósan munkanélküliek aránya, meghaladja az 50\%-ot. A pályakezdő munkanélküliek mutatója alacsony, fele az országos és harmada a megyei értékeknek (Loncsák 2018).

\section{II.4.1. A faluban maradás indokai}

Tíz darab interjú készült Nyírkércsen élőkkel. A válaszadók életkora, iskolai végzettsége, foglalkozása nagyon vegyes. A legtöbben a falusi életmód előnyeit emelik ki, csendes, nyugodt, biztonságos és otthonos voltát.

${ }^{25}$ http://www.ksh.hu/apps/hntr.telepules?p_lang=HU\&p_id=25928 


\section{TEMATIKUS TANULMÁNYOK - Községekben élő immobil fiatalok}

„Utálom a várost, utálom a gyárakat, nekem az olyan, mint egy börtön. Nem. Én itt nöttem fel, kiskoromban is a tengeri közt szaladgáltam, én nem bírnám a várost." (18 éves férfi, szakmunkás)

„Hát elsôsorban csendes, nincs olyan nagy zsongás, mint a városokban, engem a csendesség, ami megfog. Jobban ki lehet pihenni itt magunkat az embereknek itten, mint egy városba." (21 éves, érettségizett)

Ehhez szinte minden megkérdezett szerint hozzájárul az is, hogy a településen nem élnek romák. Ez azért lényeges szerintük, mert a közeli falvakban nagyon magas az arányuk.

„Itt a mi falunkban egyáltalán nincs kisebbség.” (20 éves férfi, szakmunkás)

„Baktalórántházán nagyon sok a roma, Nyírjákón is vannak, már betelepültek, Ramocsaházán is sok roma van, meg itt a környezô településeken. Egyedül Kércs az egyetlen, ahol egy vagy két család cigány van. Azt annyi." (18 éves férfi, szakmunkás)

„Etnikailag. Ha úgy nézzük, hogy nincsen kisebbség, mert az szerintem rengeteg helyen gondot jelent." (26 éves férfi, érettségizett)

„Szerintem nekünk ez a kis falu annyiban jó, hogy nincs roma, és szerintem ez, mindenkinek ez a kiindulópontja." (45 éves nö, 8 ált. iskolai végzettség)

Épp ez a biztonság tartja vissza több interjúalanyunkat is a költözéstől. Félnek az ismeretlentől, a változásoktól, az esetlegesen rájuk váró kudarctól. Ahhoz, hogy el tudjanak menni, fel kell számolniuk itteni életüket és mi lesz, ha az új lakóhely mégsem jön be.

„Hát most azért gondold el, el kell adnod a házat ahhoz, hogy tudjál venni egy másikat, aztán hiába van házad, ha nincs munkahelyed, vagy hiába mész el, ha nincs kereseted, amiből hónapról hónapra megélj. Mert szerintem az embereknek olyan sok pénzük nincs úgy lerakva, hogy abból 2-3 hónapig tudnának úgy élni, még ha nem is vennének új lakást, míg el nem adják a másikat, hogy munka nélkül tudnának élni. Biztos, hogy nagyon sok mindenkit ez tart vissza." (20 éves férfi, szakmunkás)

„A férjem mehetett volna rendörnek, Pesten kaptunk volna lakást, de szerintem féltünk attól, hogy kimozduljunk. Az, hogy idegen környezet, milyen lesz, 


\section{TEMATIKUS TANULMÁNYOK - Községekben élő immobil fiatalok}

megfelel-e a munka, ha nem felel meg, vissza kell jönnünk, találunk-e munkát mindenkinek. Féltünk a világtól." (45 éves nö, 8 ált. iskolai végzettség)

A helybeni munkalehetőség és karrier lehetősége is itt maradásra késztet. Egyik interjúalanyunk családi vállalkozásban dolgozik, állattenyésztéssel foglalkozik. Számára fontos, hogy az édesapja munkáját tovább vigye, ezáltal megtalálja saját számításait is.

„Nekem itt van minden, nekem apukám megalapozta a jövőmet, én azt nem adom fel. Hát nekem itt megvan minden. Tudok a saját magam ura lenni. Akkor hagyom abba a munkát, amikor én úgy gondolom. Nem az, hogy majd más mondja, hogy majd egy óra múlva hagyod abba, meg stb. Hát itthon van minden." (18 éves férfi, szakmunkás)

A család, a családról, a szülőkről való gondoskodás is az itt maradást indokolja.

„Hát így is, hogyha mi elmennénk, anyu, ha egyedül maradna, hát itt ki lehetne kapcsolni, az áramot, vizet, mindent. Mert ő, az ő 37 ezer forintjából 13 ezer forint a gyógyszer. Most akkor gondold el. Mire ő kifizeti a villanyszámlát, a vizet, vesz egy gázpalackot, szippantás, kaja. Annyiból hol jön ki szerinted ez? Sehol. Ha mi itt nem lennénk, vagy legalább az egyik testvérem nem marad itt, akkor ott neki vége." (35 éves nö, érettségizett)

A racionális, gazdasági jellegű indítékok között pedig megjelennek a magas lakhatási költségek, az értékükön eladhatatlan ingatlanok, amelyek miatt csak álom lehet az innen való elköltözés.

„Szerintem az a baj, hogy a lakhatóság nagyon sok pénzt elvinne a keresetemből. És így már nem érné meg, hogy én béreljek egy helyiséget. Mert nagyon-nagyon drágák a lakbérek, és ha még hozzáveszem a kaját, akkor nem maradna az ég egy adta világon semmi abból a pénzböl, amit keresnék. Semmi nem maradna." (35 éves nó, érettségizett)

Végül az idősebb életkor is a helyben maradás egyik indokaként fogalmazódott meg.

„Itt van mindenünk kész. Én már nekem az, az idő, ami hátravan, nem tudom, kinek mennyit szabnak, én nekem az már... én már nem akarok belefogni másba. Ez már megvan, ezt kell megőrizni. Nem. Igazából nem tervezem, hogy még az utolsó 20, vagy 40, vagy 30 évet még azzal foglalkozzak, hogy még 
www. metszetek.unideb.hu

\section{TEMATIKUS TANULMÁNYOK - Községekben élő immobil fiatalok}

építsem magamnak, meg... nem. Ez már megvan, ezt kell megörizni. Ezt kell használni, kész." (43 éves férfi, szakmunkás)

\section{II.4.2. Taszító tényezók, ami miatt el akarnak költözni}

Legfontosabb a helyi munkalehetőségek hiánya. A községben behatároltak a foglalkozási lehetőséget, magasabb iskolai végzettséggel, speciális szaktudással itt nem lehet megfelelő munkát találni. A megyeszékhely már ahhoz messze van, hogy érdemes lenne a mindennapos ingázást emiatt vállalni.

„A terveim között van, hogy innen el szeretnék kerülni, innen Nyírkércsről, mert hát nem látok fejlődést, és messze van a munkahelytől és a városoktól, kevés itt a lehetőség." (26 éves férfi, érettségizett)

„A munkalehetöség miatt részben, mert itt nincs úgymond. Most már én is beláttam, hogy a közelben biztos, hogy nem lesz munkahely olyan, amilyet én szeretnék, úgyhogy menni kellesz arrébb." (22 éves férfi, szakmunkás)

\section{Összegzés}

Az immobil kutatás célja, választ kapjunk arra a kérdésre, milyen okokkal magyarázható, indokolható a faluban maradás jelensége akkor, amikor minden tekintetben több előny származik a városi létből. Ennek megválaszolása érdekében olyan kis vagy közepes lakosságszámú falvakban élőkkel készültek interjúk (104 darab), akiknek többsége hátrányos helyzetű, munkanélküliséggel erősen sújtott településeken él.

A településeket két csoportba soroltuk, külön elemeztük a jelentős munkanélküliséggel sújtott és az alacsonyabb, az országos értékhez közeli vagy az alatti rátával rendelkezőket. Azt feltételezve, hogy a helyben való foglalkozás fontos indikátora az immobilitásnak. Az interjúk alapján a mobilitás vagy immobilitás valóban legtöbbet említett indoka a helybeli vagy közeli munkalehetősséggel függött össze. Minél magasabb iskolai végzettséggel, speciális szakmával rendelkezett a megkérdezett, annál nehezebb volt számára megfelelő munkahelyet az adott településen találni. Az interjúalanyok között kis számban, de előfordult ennek az ellenkezője is, azaz éppen azért marad ez egyén a településen, mert olyan szakmája van, amit az adott falu preferál (pedagógus, egyéni vállalkozó). Minél alacsonyabb volt a megkérdezett iskolai végzettsége, annál gyakoribb volt, hogy helyben szeretett volna elhelyezkedni. Hiszen a szakmanélküliség amúgy is szinte csak alacsony presztízsű munkát jelenthet lakóhelytől függetlenül, tehát a más településre való utazás csak időt és pénzt vesz el tőle, de plusz jövedelmet nem hoz. Az interjúkból az is kiderült, hogy a 


\section{TEMATIKUS TANULMÁNYOK - Községekben élő immobil fiatalok}

közmunka valóban jelentősen csökkentette a település munkanélküliségi rátáját, de nem ad egzisztenciális biztonságot, sőt sokkal inkább a kiszolgáltatottságot növeli. A megkérdezettek válaszai azt igazolják, hogy csak kényszerből vállalják el a közmunkát, szégyellik azt és nem segíti a megélhetésüket, tehát a közmunka megléte nem teszi vonzóvá az adott települést. Egyetlen interjúalanyunk volt, aki a közmunkát előnyösebbnek tartotta, mint a napszámot vagy az alkalmi munkát, mondván, hogy biztosabb és hetente fizetnek érte bért. A helybeni munkalehetőség hiánya vagy nem megfelelő volta a szülők esetében még hangsúlyosabb mobilitási tényezőként jelenik meg, főként gyerekeik viszonylatában. Jellemzően még akkor is a fiatalok elköltözését tartják reális alternatívának, ha ez egyben ritkább találkozásokat, családi együttléteket is jelent.

A helyben való munkalehetőségek hiányában marad a közeli kisvárosok felé vagy a megyeszékhely irányába történő ingázás. A távolság ugyan fontos szempont, de legalább ennyire meghatározó a buszközlekedés megléte, sűrűsége, gyorsasága is. Az interjúk azt igazolták, hogy a városok elérhetőségének lehetőségeit lényegesebb szempontnak tartják interjúalanyaink, mint a távolságot. Tehát ha 30 kilométerre kell naponta utazni, van saját személyautó vagy gyakran és gyorsan jár a busz, akkor ez a távolság még nem jelent gondot, elköltözésre indokot. (Jászszentandrás, Berkesz, Hajdúbagos) Ha nincs autó és ritka a buszjárat (Nyírkércs), akkor a 30 kilométer már erősen elgondolkodtató és költözésre motiváló lehet.

A 20 kilométernél rövidebb út esetén, különösen, ha az a megyeszékhelytől való távolságot jelenti, jellemzően összeadódnak a városi és falusi élet előnyei, a város nyújtotta szolgáltatás és a falu biztosította nyugalom, ismertség és bizalom (Apagy, Hajdúbagos, Kisgyőr). Ebben az esetben nem jelent hátrányt, ha nincs elegendő egészségügyi, oktatási intézmény, kereskedelmi szolgáltatás, szórakozási lehetőség a településen, hiszen gyakran járnak be a közeli városba és ott elintézhetőek azok az ügyek is, amelyeket lakóhelyükön nem tudnak.

Az interjúk azt is igazolják, hogy a faluban lakás előnyei és a kedvező földrajzi fekvés, ideális természeti környezet csak az egyénnek megfelelő munkalehetőség megléte esetén növelheti az immobilitást (Apagy, Jászszentandrás, Kisgyőr, Sajógalgóc).

Ugyanakkor az interjúkból az is kiderül, hogy az elköltözés vagy helyben maradás kérdéséről való döntés komplex, soktényezős folyamat. Ebben kétségtelenül fontos, de nem kizárólagos szerepe van a foglalkoztatási lehetőségeknek. Összefüggésben áll az egyén demográfiai jellemzőivel, nemével, életkorával, családi állapotával, munkaerőpiaci jellemzőivel, iskolai végzettségével, anyagi, vagyoni helyzetével, egyéni sajátosságaival, egészségi állapotával, a változásokkal kapcsolatos attitűdjével, etnikai hátterével és az adott településsel való elégedettségével is.

Ebben a tanulmányban elsősorban a településsel kapcsolatos tényezőket elemeztem, azokat a vonzó vagy taszító okokat, amelyek befolyásolhatják a településről való elköltözés vagy helyben maradás szándékát. De a szándék és a megvalósulás 


\section{TEMATIKUS TANULMÁNYOK - Községekben élő immobil fiatalok}

között sem tehetünk egyenlőségjelet, hiszen a megvalósulást még sok egyéb előre nem látható tényező is befolyásolhatja, váratlan betegség, családi állapot megváltozása, kudarcok, tragédiák stb. A közérzetről viszont pontos képet adnak, azaz a vágyakozást jól mutatják. Természetesen az is előfordul, hogy a költözést előzetes szándék nélkül váratlan körülmények kényszerítik ki és bár nem volt előre tervezett, de mégis megtörténik.

Interjúalanyaink válaszai meggyőzően bizonyítják, hogy a település nyújtotta biztonság, nyugalom és komfortosság meghatározó tényezőjének tartják, hogy élnek-e az adott településen romák és ha igen, akkor milyen arányban (Nyírkércs, Jászszentandrás, Sajógalgóc). Az, hogy mi számít magas vagy alacsony aránynak azt a környező településekhez viszonyítják. Ha a közeli falvakban kevesebb roma család él, mint az adott településen, az már elköltözésre motivál (Tiszabercel).

Az interjúk azt is igazolták, hogy a település történelmi múltja, hagyományai nem játszanak szerepet a helyben maradásban. Az ott lakók számára nem annyira vonzó tényezők, hogy ezek immobilitásukra bármilyen módon befolyást gyakorolnának (Szatmárcseke, Vizsoly, Paszab).

Egy település esetében (Nagykereki) az interjúk azt bizonyították, hogy az itt élők számára ez a falu a végállomás, innen már nincs hova menniük. Számukra az ottlét mobilitási kudarc, de reális esélyük nincs a változástatásra, hiszen alacsony iskolai végzettségúek, szakmával nem rendelkeznek, egészségi állapotúk rossz és csak helyben számíthatnak minimális segítségre családjuktól, rokonaiktól.

A 2016-os mikrocenzus adatai szerint Magyarországon a lakott lakások 98\%-a magántulajdonban van és ezek 90\%-ában a tulajdonos él (Kovács 2017). Figyelembe véve, hogy az ingatlan ára erőteljesen településfüggő, ez jelentős immobilitást növelő tényező. Emiatt az elköltözés csak akkor reális alternatíva, ha olyan tartalékkal, családi segítséggel is rendelkezik az egyén, ami lehetővé teszi, hogy az ingatlanárak közötti különbség ne számítson vagy ne meghatározó tényezője legyen döntésének. Interjúalanyaink jelentős részénél a piaci áron eladhatatlan ingatlanok hátráltatják a jobb munkahelyekkel, nagyobb fizetésekkel kecsegtető költözéssel együtt járó lehetőségek kiaknázását. Ha elfogadjuk a KSH vándorlás definícióját, mely szerint a vándorlás olyan lakóhely változtatást jelent, ami a település határának átlépésével jár, akkor azt is figyelembe kell venni, hogy 2016-ban Magyarországon a népesség több mint ötöde születése óta ugyanazon a lakcímen élt. A lakóhely változtatása szempontjából a lakosság legidősebb csoportját stabilitás jellemzi. A 65 éves és annál idősebb népesség közel 60\%-a, az 50-64 éves korosztály kétötöde még 1990 előtt költözött jelenlegi lakóhelyére. A népesség fiatalabb csoportjaiban, a 30-49, illetve a 15-29 évesek között azok vannak a legtöbben, akik az elmúlt hat évben költöztek jelenlegi lakóhelyükre, míg a 15 év alatti lakosság többsége születése óta ugyanazon a lakcímen él. A népesség 52\%-a ugyanazon a településen lakik, mint születésekor, további $23 \%$ ugyanabban a megyében. A fiatalabb korcsoportok nagyobb arányban 


\section{TEMATIKUS TANULMÁNYOK - Községekben élő immobil fiatalok}

élnek azon a településen, ahol születtek. A 30 év alattiak 70, a 30-49 évesek 46, az 50 éves és annál idősebbek 41\%-a él a születéskori lakóhelyén.

A lakóhely stabilitása a községek lakóit jobban jellemzik, mint a városlakókat. A községek lakosainak 56\%-a, a városlakók fele él születése óta ugyanazon a településen. A születési hely elhagyása a közép-magyarországi, a stabilitás az észak-alföldi régiót jellemzi leginkább. A Jász-Nagykun-Szolnok és a Hajdú-Bihar megyei lakosok több mint kétharmada lakik születése óta ugyanazon a településen, a Pest megyeieknél csak 45\%-os az arány (Kovács 2017).

15. táblázat: A lakóhelyüket nem változtatottak aránya százalékban, a vizsgálatban szereplő megyékben 2016

\begin{tabular}{|l|c|c|c|}
\hline \multicolumn{1}{|c|}{ Megnevezés } & $\begin{array}{c}\text { Születése óta jelenlegi } \\
\text { lakcímén lakik }\end{array}$ & $\begin{array}{c}\text { Településen } \\
\text { belül mozog }\end{array}$ & Összesen \\
\hline Borsod-Abaúj-Zemplén & 24 & 38 & 62 \\
\hline Hajdú-Bihar & 21 & 45 & 66 \\
\hline Heves & 21 & 35 & 56 \\
\hline Jász-Nagykun-Szolnok & 20 & 48 & 66 \\
\hline Szabolcs-Szatmár-Bereg & 27 & 38 & 65 \\
\hline Magyarország & 20 & 31 & 51 \\
\hline
\end{tabular}

Forrás: Saját szerkesztés Mikrocenzus 2016. adatai alapján (Kovács 2017)

A 15. számú táblázat adatai azt igazolják, hogy a vizsgálatban szereplő megyékben élők még az országos értéknél is ritkábban költöznek. A Szabolcs-Szatmár-Bereg megyeiek több mint egynegyede még sohasem költözött, de a Hajdú-Bihar és Jász-Nagykun-Szolnok megyei lakosok közel fele sem hagyta el azt a települést, ahova született.

\section{Irodalom}

105/2015. (IV.23.) Kormányrendelet a kedvezményezett települések besorolásáról és a besorolás feltételrendszeréről https://net.jogtar.hu/jogszabaly?docid=A1500105.KOR Letöltés ideje: 2019. 09. 06.

Bihi M. (2018): Polgármesteri köszöntő. https://www.vizsoly.hu/polg.php Letöltés ideje: 2019. 01. 03.

http://nyirkercs.hu/bemutatkozas Letöltés ideje: 2019. 01. 03.

http://www.jaszszentandras.hu/jelen Letöltés ideje: 2019. 01. 04.

https://apagy.hu/?staffs=a-kallay-csaladrol Letöltés ideje: 2019. 01. 02. https:// tiszanana.hu/2009/04/19/a-telepueles-foeldrajza/ Letöltés ideje: 2019. 01.05. 


\section{TEMATIKUS TANULMÁNYOK - Községekben élő immobil fiatalok}

Kékedi L. Zs. (2018): Polgármesteri köszöntő http://kisgyor.hu/elemek/keret.php?redirect=keret.php\&oldal=kezdo_oldal Letöltés ideje: 2019. 01. 02.

Kovács M. (szerk.) (2017): Mikrocenzus 2016. 3. https://www.ksh.hu/docs/hun/ xftp/idoszaki/mikrocenzus2016/mikrocenzus_2016_3.pdf Letöltés ideje: 2019. 01.06.

Krémer B. (2018): Szempontok az „immobilitás-kutatás” feldolgozásához és elemzéséhez. MTA Kiválósági Együttműködési Program „Immobil falusi fiatalok” Debreceni Egyetem Szociológia és Szociálpolitika Tanszék. Kézirat, 2018. 10. 30.

Loncsák N. (2018): Települési adatok. MTA Kiválósági Együttműködési Program „Immobil falusi fiatalok”. Mobilitási Kutatási Centrum, Debreceni Egyetem Szociológia és Szociálpolitika Tanszék. Kézirat

Magyarország helységnévtára 2018. http://www.ksh.hu/apps/hntr.main?p_lang=HU Letöltés ideje: 2019. 01. 02.

Nagykereki esélyegyenlőségi terve 2018-2022. www.nagykereki.hu/eselyegyenloseg2018-2022 Letöltés ideje: 2019. 01. 02.

Orbán K. (2018). Lépések Tiszanána szegregátumban élők életminőségének javításáért - ppt. www./tiszanana.hu/lepesek-tiszananan-a-szegregatumban-elokeletminosegenek-javitasaert/ letöltés ideje: 2019. 01. 04.

Szántó Zs. (2018): Polgármesteri köszöntő https://www.tiszabercel.hu/?q=node/65 Letöltés ideje: 2019.01. 03.

Szatmárcseke a község bemutatkozása http://szatmarcseke.hu/index.php/a-telepuelesrl/kozseg-bemutatasa Letöltés ideje: 2019. 01. 02.

Tajthy P. (2018): Polgármesteri köszöntő. www.paszab.hu Letöltés ideje: 2019. 01. 02.

Településünkről https://www.paszab.hu/node/3). Letöltés ideje: 2019. 01. 02.

Zilai K (2018): Polgármesteri köszöntő www.nagykereki.hu 